\title{
DECADENCIA E INTENTOS DE REFORMA DE LA MÚSICA ECLESIÁSTICA ESPAÑOLA EN EL SIGLO XIX
}

\author{
POR \\ PAULINO CAPDEPÓN VeRdú ${ }^{1}$ \\ Universidad de Castilla-La Mancha, Centro de Investigación y Documentación Musical
}

\begin{abstract}
RESUMEN
Este artículo se centra en la decadencia que experimentó la música eclesiástica española desde comienzos del siglo XIX coincidiendo con el estallido de la Guerra de la Independencia. Dicha decadencia se agravó a consecuencia de la aplicación de las sucesivas desamortizaciones por los distintos gobiernos liberales y de la firma del concordato de 1851. Para remediar tal situación se propusieron distintos proyectos de reforma e iniciativas por parte de autores como Eslava, Barbieri, Pedrell u Olmeda, con el objetivo final de revitalizar la música religiosa de España y las capillas musicales que la sustentaban: tales proyectos, que adquirieron notable impulso gracias al movimiento cecilianista, constituyen el prolegómeno de la promulgación del Motu Proprio por el Papa Pío X en 1903.
\end{abstract}

PALABRAS CLAVE: decadencia; reforma; música religiosa; España; capilla musical.

\section{DECADENCE AND REFORM PROJECTS OF 19TH CENTURY SACRED MUSIC IN SPAIN}

\begin{abstract}
This article focuses on the decadence experienced by Spanish sacred music since the beginning of 19th century, coinciding with the outbreak of the Independence War. This decline was aggravated by the application of successive disentailments by the liberal governments and the signing of the 1851 Concordato. To remedy this situation, various reform projects and initiatives were proposed by authors such as Eslava, Barbieri, Pedrell or Olmeda, with the final objective of revitalizing religious music in Spain and the musical chapels that supported it: such projects, which gained considerable momentum thanks to the Cecilianist movement, constitute the prolegomenon of the promulgation of the Motu Proprio by Pope Pius X in 1903.
\end{abstract}

KEY WORDS: decadence; reform; sacred music; Spain; music chapel.

Cómo CITAR este artículo / Citation: Capdepón Verdú, Paulino. 2019. «Decadencia e intentos de reforma de la música eclesiástica española en el siglo XIX». Hispania Sacra 71, 144: 641-658. https://doi.org/10.3989/hs.2019.046

$\begin{array}{ll}\text { Recibido/Received } & 30-12-2017 \\ \text { Aceptado/Accepted } & 21-04-2019\end{array}$

\section{INTRODUCCIÓN}

La música religiosa significó el centro neurálgico de la actividad y creación musical en España hasta comienzos del siglo XIX. Sin embargo, las sucesivas desamortizaciones que se aplicaron en la España de la primera mitad del siglo XIX,

\footnotetext{
1 paulino.capdepon@uclm.es / ORCID iD: https://orcid.org/0000-0001-6509-3496
}

así como la firma del Concordato de 1851 entre el gobierno de la nación y la Santa Sede motivaron la decadencia de la actividad de las capillas musicales pertenecientes a catedrales, monasterios, abadías, colegiatas e iglesias parroquiales, que hasta entonces habían constituido la principal fuente de trabajo para el músico español. Ello no fue óbice para que se crearan obras musicales de gran altura, buena prueba de lo cual es la producción musical sacra de autores como 
Hilarión Eslava, ${ }^{2}$ Mariano Rodríguez de Ledesma, ${ }^{3}$ Francisco Andreví ${ }^{4}$ o Nicolás Ledesma, entre otros.

FIGURA 1

Hilarión Eslava (1807-1878)

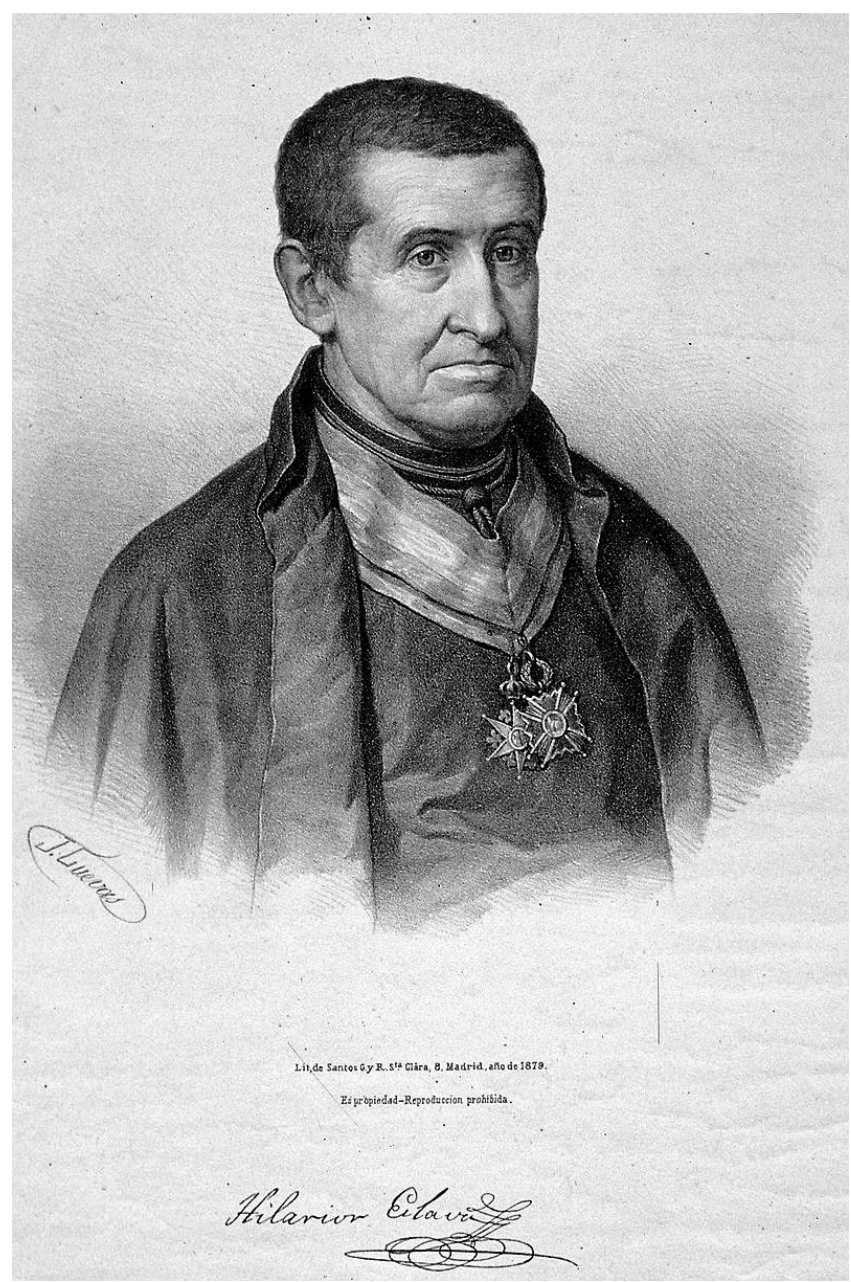

Fuente: Wikipedia. https://es.wikipedia.org/wiki/Miguel_Hilari\%C3\% B3n_Eslava\#/media/Archivo:Hilari\%C3\%B3n_Eslava.jpg

La profesora María Antonia Virgili (1995: 375-376) afirma al respecto que si con anterioridad a la Guerra de la Independencia todavía se mantenían en las capillas musicales religiosas algunos de los esplendores del pasado, desde el estallido de la contienda bélica se inicia una fase crítica que se extiende hasta el Concordato de 1851: la Iglesia española atravesó por una difícil situación económica que se tradujo en el empobrecimiento de la vida musical religiosa al no poder mantener la infraestructura necesaria (salarios de cantores e instrumentistas, adquisición de instrumentos, etc.). Hasta tal punto fue desesperada la situación que los cabildos autorizaron a los componentes de las capillas para

2 Sobre la figura de Hilarión Eslava, véase Guaza y Guerra 1884a; Saint-Martin 1973; Arana Martija 1976; Hernández Ascunce 1978; Ansorena 1978; Ayarra 1979; Gosálvez 1995; Ansorena 1999 y Capdepón 2018b.

3 En torno a Mariano Rodríguez de Ledesma, consúltese Lozano 1895; Mitjana 1909; Llorens Castillo 1979; Broto 1986; Mitjana 1993; Alonso 1998; Garrido 2002; Heilbron 2003; Capdepón 2016b y Capdepón 2018c.

${ }^{4}$ Sobre este autor véase Perpiñán 1897; Miró 1942; Subirá 1959; Baldelló 1962; Bonastre 1999; Ezquerro 2016 y Capdepón 2018a.
FIGURA 2

Nicolás Ledesma (1791-1883)

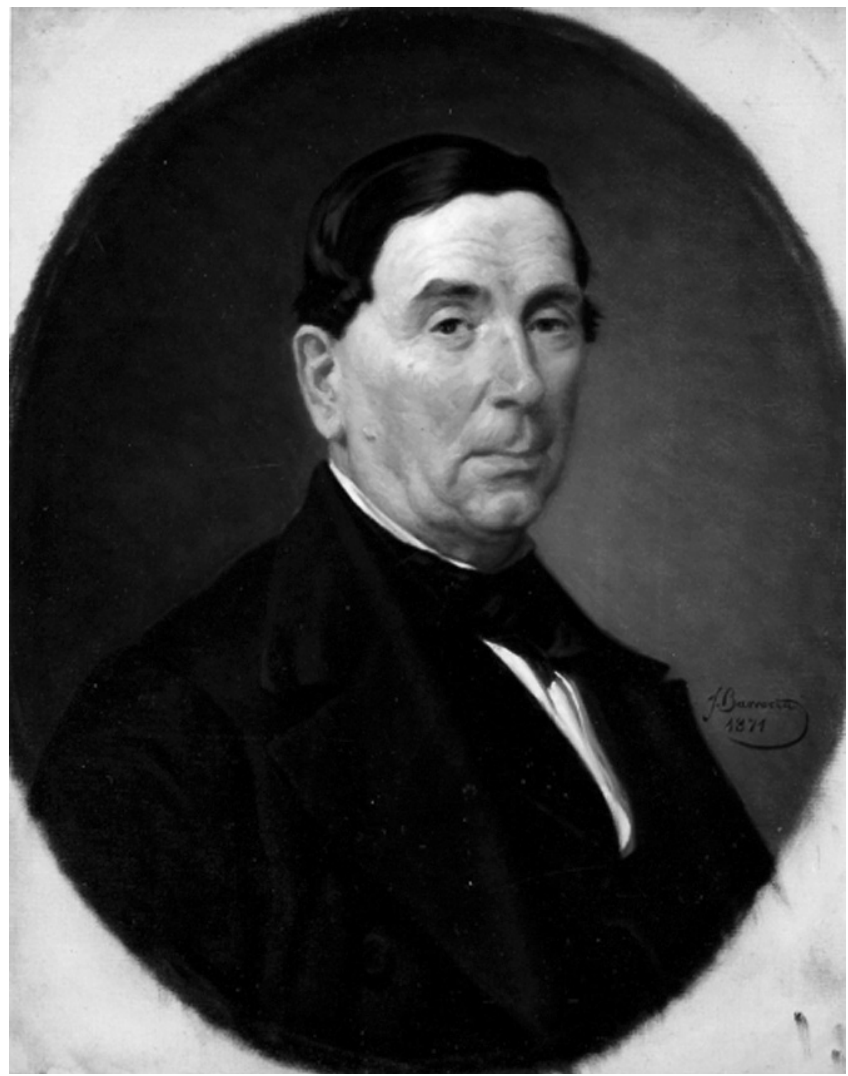

Fuente: Mis museos.net. http://mismuseos.net/comunidad/meta museo /recurso/retrato-del-compositor-nicolas-ledesma/0ff8a6a87c78-4dda-b077-2eddb391848a

que buscaran trabajo en otro lugar, garantizándoles la recuperación de su antiguo trabajo en la catedral en el caso de que mejoraran las circunstancias económicas. En las capillas que sobrevivieron, sus efectivos se redujeron drásticamente, viéndose los cabildos obligados a contratar a músicos ajenos a las catedrales (músicos de la propia ciudad o de fuera e incluso seminaristas) para las festividades que requerían una dotación vocal-instrumental mayor. Hubo sin embargo excepciones como la protagonizada por la Real Capilla de Madrid, que pudo mantener gracias a su estatus especial una plantilla más o menos uniforme, permitiendo a los diferentes maestros de dicha institución crear obras de gran formato acordes a la solemnidad requerida para los servicios litúrgicos cortesanos. ${ }^{5}$ En referencia a ello, afirma Begoña Lolo (1996: 122) que «a pesar del inquietante estado de decadencia de la música litúrgica propiciado por la crisis que soportaban las capillas catedralicias, en unos momentos en los que la secularización y pérdida de poder monárquico empezaban ya a planear en la Historia, la Real Capilla permaneció ajena al contexto nacional manteniendo el esplendor y la grandeza característica de la monarquía borbónica».

5 La Real Capilla de Madrid estaba integrada en 1815 por un total de 50 músicos: un maestro de capilla, 4 organistas, 2 trompas, 2 fagotes, 10 violines, 2 violas, 3 violones, 3 contrabajos, 4 oboes/flautas, 2 clarines, 2 clarinetes, 4 tiples, 4 contraltos, 4 tenores y 3 bajos (Lolo 1995). Sin embargo, en la plantilla de 1824 ya se percibe un claro retroceso en el número de efectivos, pasando de 50 miembros a 40, es decir un $20 \%$ menos (Lolo 1996: 121). 
FIGURA 3

Práctica del coro, de José Gallegos Arnosa (1857-1917)

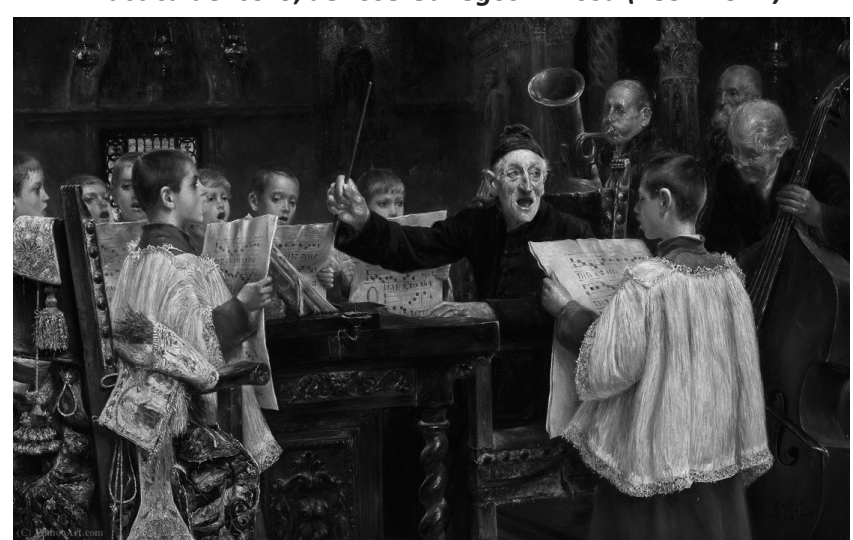

Fuente: Wikioo. http://wikioo.org/es/paintings.php?refarticle=A2A8D S\&titlepainting=Choir\%20 practice\&artistname=Jose $\% 20$ Gallegos\%20 Y\%20Arnosa

La situación generalizada de decadencia y retroceso de la música española sacra durante el siglo XIX está acreditada por numerosos pronunciamientos contemporáneos que así lo atestiguan. Valga como ejemplo el del compositor y musicólogo belga François-Auguste Gevaert, quien transmitió una desoladora panorámica sobre la música religiosa española para órgano con ocasión de la concesión del Premio Roma, teniendo la oportunidad de visitar Francia, Italia, España y Alemania entre 1849 y 1852 . Finalizada su estancia en dichos países, Gevaert preparó una detallada memoria que presentó al Conservatorio de Bruselas en 1852, memoria que fue incluida posteriormente por el musicólogo y crítico francés François-Joseph Fétis (1784-1871) en la Gazette musicale de París. Entre otros aspectos, se refiere Gevaert de la siguiente manera a sus impresiones sobre la música organística que escuchó en nuestro país:

Los organistas que he escuchado durante mi estancia en la Península, merecen por lo general una baja valoración; es imposible imaginar algo más plano, incoherente y de mal gusto que las piezas que ejecutan, si es que se puede decorar del título de piezas las clases de preludios abortados sin tema y sin ningún tipo de plan o unidad; en fin, una música que no es tal y donde el artista más indulgente busca en vano una chispa de talento. Por lo demás, dudo que este país, incluso en su época más dorada, haya tenido organistas de talento trascendente porque desde mi llegada a España no he visto una sola obra para este instrumento, escrita por un artista nativo (Gevaert 1852: 191). ${ }^{6}$

6 Les organistes que j'ai entendus, pendant mon séjour dans la Péninsule, sont en général au-dessous de toute critique; il est impossible de s'imaginer rien de plus plat, de plus incohérent, de plus mauvais goût que les morceaux qu'ils exécutent, si toutefois l'on peut décorer du titre de morceaux des espèces de préludes avortés, sans sujet, sans plan, sans unité, enfin une musique qui n'en est pas une et où l'artiste le plus indulgent cherche en vain une étincelle de talent. Du reste, je doute que ce pays, même à son époque la plus brillante, ait possédé des organistes d'un talent transcendant, car depuis mon arrivée en Espagne, je n'ai pas vu un seul morceau pour cet instrument écrit par un artiste indigène. Traducción de Paulino Capdepón.
Figura 4

François-Auguste Gevaert (1828-1908)

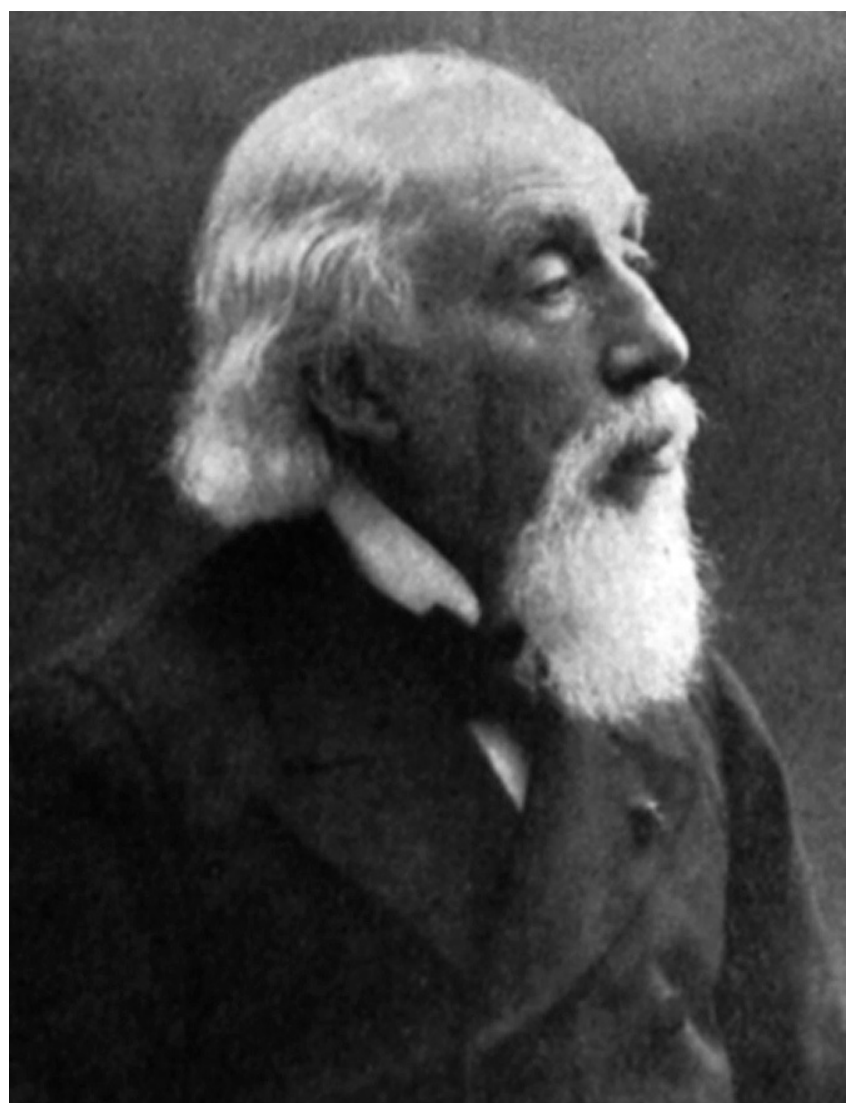

Fuente: Wik ipedia. https://es.wikipedia.org/wiki/Fran\%C3\%A7oise_ Auguste_Gevaert\#/media/Archivo:Fran\%C3\%A7ois-Auguste_ Gevaert_photo_c1896_-_IMSLP.jpg

FIGURA 5

François-Joseph Fétis (1784-1871)

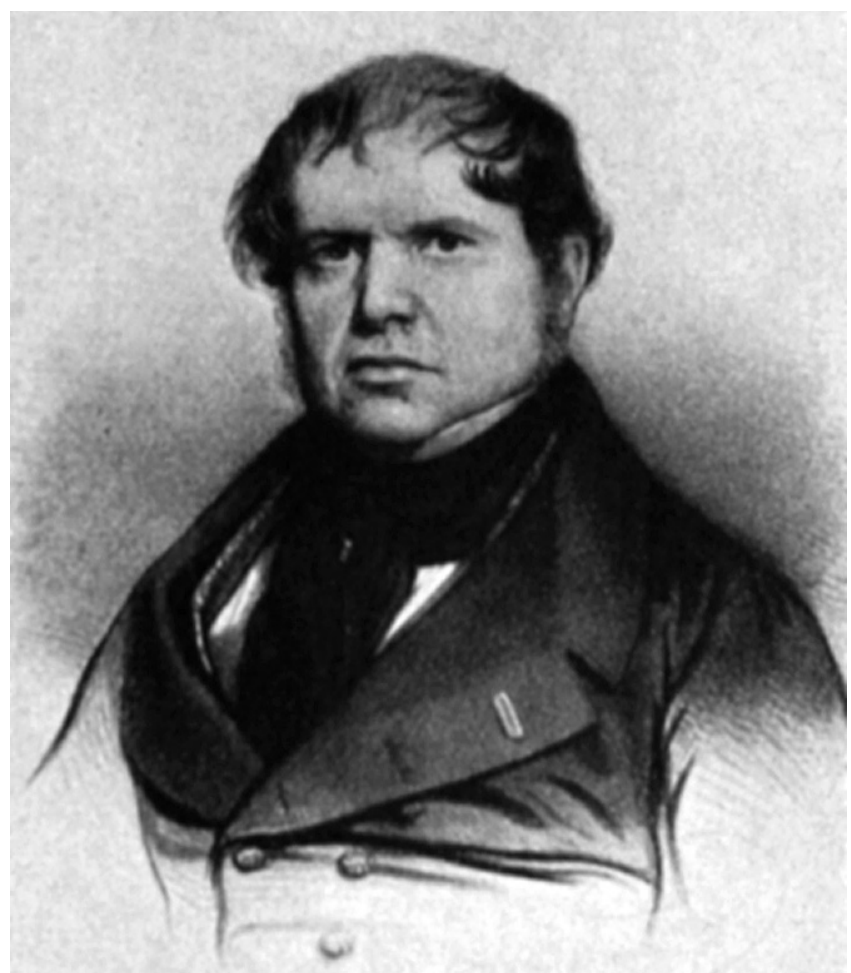

Fuente: Wikipedia. https://es.wikipedia.org/wiki/Fran\%C3\%A7oisJoseph_F\%C3\%A9tis\#/media/Archivo:Francois_joseph_fetis.jpg 
Hilarión Eslava fue el primer autor español en reaccionar ante la opinión de Gevaert y precisamente una de las razones que le impulsaron a editar su obra Museo orgánico español fue rebatir semejante tipo de apreciaciones negativas sobre la música española del pasado:

Los males que resultan de no poseer la historia nacional del arte son muy trascendentales. Esta falta, aparte de otras consideraciones graves, es denigrante para una nación como la España, que tiene derecho a figurar como musical, por las felices disposiciones de sus naturales, y por los muchos y grandes profesores que ha dado en todos tiempos, y en diversos ramos del arte. Es además muy sensible ver que los artistas extranjeros que viajan por España, y que, no teniendo otro medio de instruirse en nuestra historia musical, sacan sus apuntes por conjeturas, o por noticias las más veces erróneas, formando después con ellas memorias y relaciones llenas de inexactitudes y errores muy perjudiciales al arte músico-español. En una de estas memorias, escrita con talento y buen criterio en su mayor parte por mi buen amigo el Sr. Gevaert, y comentada después en la Gaceta musical de París por el eminente escritor Sr. Fétis, á quien debe el arte grandes servicios y yo finísimas atenciones, se ha incurrido en un error grave, diciendo con la mejor buena fe, pero sin los datos suficientes y por solas conjeturas, que en España no sólo no hay en el día buenos organistas, sino que no los ha habido jamás. Si estos excelentes profesores hubieran adquirido los verdaderos conocimientos de la historia de este ramo, es de creer que hubiera sido otra su opinión en esta materia (Eslava 1853: 5-6).

Un segundo testimonio surgió años después, concretamente en 1874, gracias a un artículo de José María Esperanza y Sola bajo el título de "Herejías musicales»: ${ }^{7}$ en dicho artículo el autor desgranaba sus impresiones en torno a la música sacra española de su época y afirmaba lo siguiente:

Cantar las alabanzas del Altísimo; elevar a Él nuestras plegarias, invocando su misericordia, y encender nuestro corazón en afectos de amor, de ternura, de gratitud y de arrepentimiento: he aquí los grandes objetos de la música religiosa, la cual, para cumplirlos, necesita, tanto o más que de la inspiración y de la corrección, de la verdad, esto es, que sea eco fiel y poderoso y eficaz auxilio de la letra. Tratar sólo de prescindir de esto, y más aún, hacer caso omiso del sentido de las palabras, es un verdadero sacrilegio musical, porque no se concibe (iy, sin embargo, se hace!) cantar con ritmos impropios de la majestad y severidad del templo el temible Dies irae del oficio de difuntos, el grandioso salmo Benedictus Deus Israel (escrito de una manera tan admirable en fabordón por el prebendado alcalaíno Lorente) y hasta el Gloria y el Hosanna, cuya alegría requiere algo que no sea mundanal y terreno; que el Cristianismo, como decía Chateaubriand, es grave hasta en su sonrisa (Esperanza y Sola 1906a: 78).

Hace alusión asimismo Esperanza y Sola a las opiniones de Gevaert y a los sucesivos intentos de reforma de la música eclesiástica en España para llegar a la conclusión que han fracasado:

7 Este artículo fue publicado originalmente en la revista La España católica el 28 de septiembre de 1874 y fue reproducido en una antología de sus críticas en 1906, un año después del fallecimiento de Esperanza y Sola, bajo el título de Treinta años de crítica musical.
$Y$ en cuanto a nuestra patria, basta leer respecto al pasado siglo los escritos del ya citado Feijóo, y en cuanto al presente, la Memoria escrita a la vuelta de su viaje artístico por el hoy Director del Conservatorio de Bruselas, F. A. Gevaert, para convencerse del triste y deplorable estado a que había venido á parar. Así ha seguido por largo tiempo, víctima de la ignorancia y del deplorable gusto que en las Bellas Artes reinaba, hasta que, aún no hace muchos años, se ha empezado a obrar una reacción, tal vez algo exagerada, en el extranjero, y que aunque aquí ha contado con excelentes y fervorosos adeptos, no ha llegado a extender su dominio cual fuera de desear y por razones que no acierto a comprender (Esperanza y Sola 1906a: 80).

Esperanza califica en su artículo la música que se escucha en los templos españoles en la década de los años 70 del siglo XIX como «vulgar» y «profana»:

Es una verdad amarga, pero es una gran verdad: la música que comúnmente se oye en nuestros templos no tiene ninguna, absolutamente ninguna de las esenciales condiciones que el género eclesiástico, digámoslo así, requiere. Vulgar, vulgarísima, incorrecta, es además profana hasta un punto inconcebible. España, que cuenta en los archivos de sus catedrales inapreciables tesoros de la verdadera música religiosa, verdaderos modelos de saber y de inspiración; España, que entre sus glorias artísticas tiene la de que un hijo suyo fuera el primero que a sus composiciones aplicase, como ya hemos dicho, la verdad y la expresión, ${ }^{8}$ reniega de su pasado, y si no ha caído en la confusa dialéctica de un contrapunto que nada expresa ni conmueve, ha olvidado sus tradiciones aplicando a las poéticas palabras de los libros santos, de cuyo sentido no hace gran caso cuando no prescinde por completo, ritmos y cadencias impropios de todo punto (Esperanza y Sola 1906a: 80-81).

Esperanza contrapone la situación de la música sacra española de su tiempo con el esplendor del pasado, citando concretamente como modelo de perfección la música de Tomás Luis de Victoria, Antonio Soler e incluso Hilarión Eslava:

No busque usted, no, amigo mío, al entrar en nuestros templos, que su alma encuentre suave consuelo con la unción que a su música prestaba Victoria, cuyo motete Vere languore nostros es aún hoy admiración de propios y extraños; que se inflame con la inspiración de un Soler, y para hablar de más modernos tiempos, que con la severidad y corrección de las obras de nuestro eminente Eslava se inspire en las grandezas del Cristianismo, no; excepción hecha de la capilla de Palacio, asilo hasta muy modernos tiempos de las tradiciones de la buena música, lo que encontrará usted serán trozos de ópera, composiciones insípidas, olvido absoluto de lo que la ciencia y el buen sentido aconsejan. Ya es un trozo de zarzuela..., ya es un aria de ópera italiana (1906a: 81).

Sería necesario esperar a finales de siglo para que se intente modificar la música sacra española, a imitación de las corrientes reformistas de Alemania y Francia, tal como comprobaremos posteriormente. Así pues, es necesario estudiar tres elementos clave para entender la evolución de la música religiosa española del XIX: las desamortizaciones, el Concordato de 1851 y las propuestas de reforma de la música sacra.

\footnotetext{
8 Se refiere el autor a Cristóbal de Morales.
} 
FIGURA 6

José María Esperanza y Sola (1834-1905)

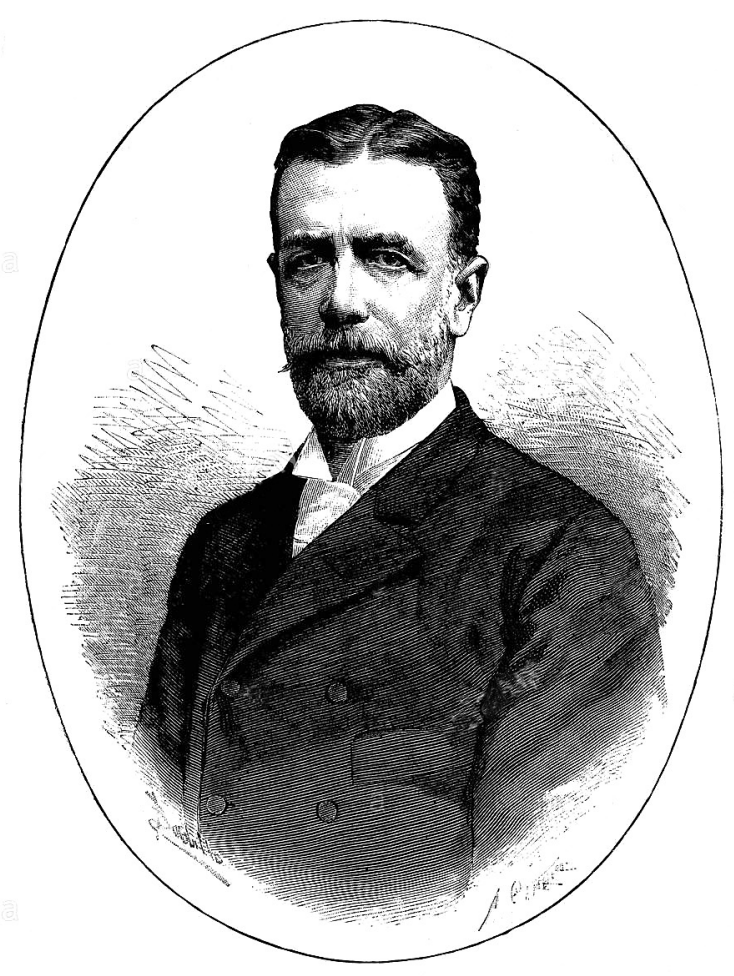

D. JOSÉ MARIA ESPERANZA Y SOLA.

Fuente: Alamy. https://www.alamy.com/jos-mara-esperanza-y-solacrtico-musical-espaol-grabado-de-1889-image209706327.html

\section{LAS DESAMORTIZACIONES}

Varios estudios han abordado las consecuencias que conllevaron la expropiación de los bienes eclesiásticos a lo largo del siglo XIX. En concreto, Antonio Gallego (1991: 14) citaba que era necesario ampliar el análisis de las desamortizaciones, añadiendo, entre otras cosas, que como resultado del proceso desamortizador «se ha cegado para siempre el sistema que durante siglos había funcionado como eje de transmisión del oficio de músico: los colegios de niños cantorcicos, escolanes, infantejos...». Posteriores estudios (Martín Martín 2005 o Myers Brown 2005 y 2007) han hecho hincapié en aspectos particulares que ilustran los negativos efectos que provocaron los diferentes procesos desamortizadores sobre la conservación del patrimonio musical religioso en la España del ochocientos.

No podrían comprenderse dichos procesos del siglo XIX sin remontarse a los antecedentes del siglo XVIII, concretamente a la Pragmática Sanción de Carlos III: ${ }^{9}$ aunque dicha norma legislativa afectó en exclusiva a la Compañía de Jesús, estableció un claro precedente para futuras intervenciones desamortizadores del Estado. ${ }^{10}$ Durante la ocupación francesa,

9 Una amplia visión de la legislación en torno a las desamortizaciones de los siglos XVIII y XIX puede consultarse en Campos y Fernández de Sevilla 2007: 5-30.

10 El título completo de dicha norma era Pragmática Sancion de su Majestad en fuerza de ley para el extrañamiento de estos Reynos á los Regulares de la Compañia, ocupación de sus Temporalidades, y prohibicion de su restablecimiento en tiempo alguno, con las demás precauciones que expresa.
José I inició una serie de decretos encaminados a la reducción del número de conventos, impidiendo a los que sobrevivieron la admisión de nuevos novicios hasta que se llegara a la tercera parte de los conventos existentes en aquel momento. ${ }^{11}$ Además, en 1809 el monarca francés dictó una orden, por la que, además de los impuestos ordinarios, se exigía al clero español un empréstito obligatorio de cien millones de reales, así como la entrega de la plata, alhajas y todo tipo de objetos preciosos (Virgili 1995: 377-378). Aquel mismo año y según decreto de 18 de agosto, José I suprimió todas las órdenes regulares, monacales, mendicantes y clericales, y el abandono en 15 días de todos los religiosos de sus conventos, obligándoles a vestirse con hábitos clericales seculares; por otra parte, se forzó a los frailes a regresar a sus pueblos y ciudades de origen, donde tendrían la posibilidad de ser empleados en curatos, dignidades, etc., según su mérito y conducta así como recibir una pensión (Myers 2005: 314). ${ }^{12}$

Nuevos decretos (22 de julio de 1809 y 3 de marzo de 1813) establecían que todas las propiedades de los conventos extinguidos pasaban a formar parte de los Bienes nacionales, las cuales podían ser subastadas o arrendadas por los municipios.

A diferencia de los cuadros y librerías, considerados como objetos de interés artístico o científico, los objetos relacionados con la música (libros de coro, sillerías, órganos, partichelas, facistoles, etc.) tuvieron el tratamiento de «objetos propios de culto" y los reales decretos de 3 de marzo y 6 de septiembre de 1809 dictaban a su vez que dichos objetos, junto con los vasos sagrados ornamentos de culto, etc., estarían destinados a las iglesias necesitadas, tal como ha destacado María Dolores Antigüedad (1987: 88): entre las iglesias «necesitadas» de Madrid que reclamaron, entre otros objetos, «libros cantorales», "misales» y "órganos»,

11 Consúltese al respecto el trabajo de Mercader Riba 1972.

12 El Real Decreto de José Napoleón I (18 de agosto de 1809) dice así: "No habiendo bastado todos los miramientos que hemos tenido hasta ahora con los regulares de las diferentes órdenes, ni las promesas sinceras que les habíamos hecho de dispensarles nuestra protección y favor, en cuanto la equidad y el interés general del reino lo permitiesen, evitando todo perjuicio individual, para que ellos hayan permanecido tranquilos, sin tomar parte, según lo exige su estado, en las turbulencias y discordias que afligen actualmente a la España; habiendo el espíritu de cuerpo impedido que hayan confiado en nuestros ofrecimientos, y arrastrándoles a disposiciones hostiles contra nuestro Gobierno; lo que de un instante a otro habría acarreado su perdición individual en perjuicio de las leyes, de la religión y de la justicia; y queriendo reservarnos los medios de recompensar los religiosos que se conduzcan bien, elevándolos a todos los empleos y dignidades eclesiásticas, como a los individuos del clero secular; oído nuestro Consejo de Estado, hemos decretado y decretamos lo siguiente: I. Todas las Ordenes Regulares, Monacales, Mendicantes y Clericales que existen en los dominios de España quedan suprimidas; y los individuos de ellas, en el término de quince días, contados desde el de la publicación del presente decreto, deberán salir de sus conventos y claustros y vestir hábitos clericales seculares. II. Los Regulares secularizados deberán establecerse en los pueblos de su naturaleza, donde recibirá cada uno de la Tesorería de Rentas de la provincia la pensión que está señalada por el decreto de 27 de abril de este año. III. Los que tuviesen motivos para no trasladarse a los pueblos de su naturaleza, los harán presentes al Ministerio de Negocios Eclesiásticos; y hallándolos éste justos, les señalará los parajes donde podrán permanecer, y les será pagada su pensión. IV. Los prelados actuales de los monasterios y conventos, y todos los individuos de las comunidades serán mancomunadamente responsables de toda extracción u ocultación de los bienes, así muebles como raíces, pertenecientes a sus respectivas casas...» (citado en Campos y Fernández de Sevilla 2007: 10-11). 
se encuentran los monasterios reales de la Encarnación y de las Descalzas Reales. En opinión de Sandra Myers,

\begin{abstract}
las medidas tomadas por José I para la creación de un museo en París, añadidas a las extracciones y fraudes realizados por altos cargos militares y comisiones particulares, y al comportamiento de expolio absoluto de bienes muebles e inmuebles por parte de las tropas francesas durante la guerra -hecho corroborado por innumerables testigos de la época-, indudablemente afectaron una cantidad considerable de bienes artísticos, incluyendo fuentes musicales. Es llamativo lo que escribe, en 1854, el canónigo José Quevedo sobre lo ocurrido, por ejemplo, en el Monasterio de El Escorial, explicando cómo los libros de coro, junto con los demás objetos de bellas artes del monasterio, fueron empaquetados y llevados en 300 carretas y 500 caballerías, reunidos a tal efecto de los pueblos inmediatos, a Madrid por orden del "impío francés» y comisario de artes, Federico Quilliet (Myers 2007: 86-87). ${ }^{13}$
\end{abstract}

Las Cortes de Cádiz habían dictaminado por decreto de 17 de junio de 1812 la supresión de los conventos con menos de 12 miembros y la incorporación al Estado de los bienes de las órdenes religiosas disueltas o reformadas durante la etapa del gobierno intruso. Sin embargo, un decreto general de desamortización de 13 de septiembre de $1813^{14}$ no pudo aplicarse debido a la restauración del absolutismo por parte de Fernando VII, a pesar de lo cual sentó las bases para las futuras medidas desamortizadoras de los gobiernos liberales como medida para sanear las cuentas de la Hacienda estatal (Tortella 1994: 46). Fernando VII devolvió a sus anteriores dueños las propiedades desamortizadas durante el gobierno intruso.

FIGURA 7

El Coro de niños de Sevilla, de José Gallegos Arnosa

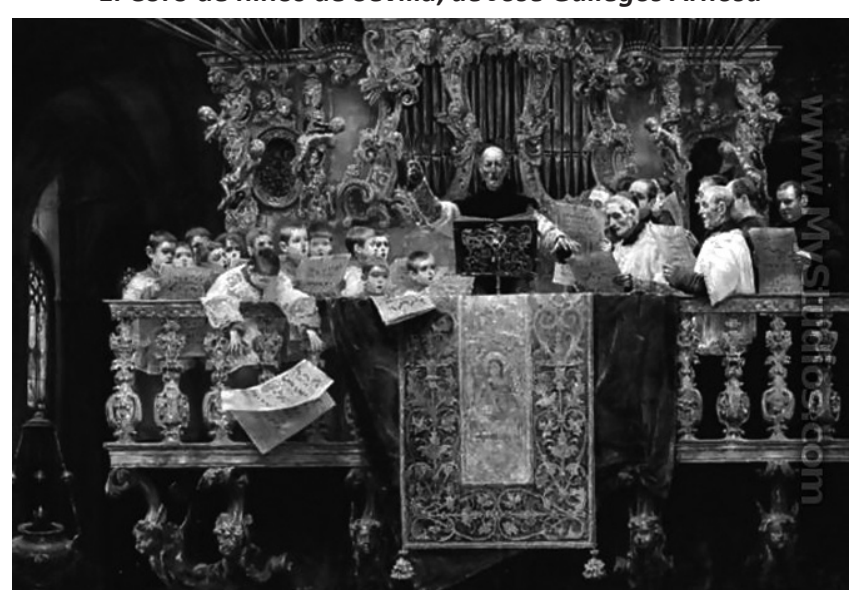

Fuente: academiacolecciones.com. https://www.academiacolecciones. com/pinturas/inventario. php ?id=1464\#\&gid=1\&pid=1464

13 Sobre el expolio napoleónico, véase asimismo García Serrano (s. f.) [consultado: mayo, 26, 2017]

${ }^{14}$ Según el Decreto de las Cortes (13 de septiembre de 1813), se ordena la clasificación y pago de la Deuda nacional, señalando hipotecas para el pago de los intereses y extinción de capitales. Entre los bienes designados para formar la hipoteca, están: "XVII.2. Los de las Temporalidades de los Jesuitas. 3. Los de la Orden de San Juan de Jerusalén. 4. Los predios rústicos y urbanos de los Maestrazgos y Encomiendas vacantes y que vacaren en las cuatro Órdenes Militares. 5. Los que pertenecían a los conventos y monasterios arruinados y que queden suprimidos por la reforma que se haga de los regulares....» (citado en Campos y Fernández de Sevilla 2007: 11).
Durante el Trienio liberal (1820-1823) sí pudo aplicarse una desamortización general que afectó especialmente a los bienes del clero regular, según los reales decretos de 17 de agosto, del 1 de octubre y del 17 de octubre de 1820 y en la ley de 25 de octubre del mismo año. Recogiendo el espíritu de las Cortes de Cádiz, se decretaba que aquellos conventos con menos de doce miembros, serían suprimidos, y no se mantendría más de un convento de una misma orden en cada pueblo y su término; los archivos de los conventos suprimidos se trasladarían a los archivos de las respectivas vicarías eclesiásticas, procediéndose al inventario de todos lo bienes: el método para la elaboración de los respectivos inventarios de bienes pertenecientes a los conventos, monasterios y demás instituciones suprimidas ${ }^{15}$ se estableció en el real decreto de 1 de octubre de 1820 y en la real orden de 29 de octubre del mismo año. Concretamente, en el inventario conservado en el Archivo Histórico Provincial de Toledo los objetos relacionados con la música están clasificados en el apartado 50:16 libros de coro, misales, facistoles y órganos fueron considerados como «objetos destinados al culto" y no como "objetos artísticos», por lo que, al igual que sucedió en la época de José I, fueron destinados a otras iglesias, conventos o parroquias que los necesitasen.

Especial incidencia tuvo para las catedrales españolas la aplicación del decreto del 29 de junio de 1821 reduciendo a la mitad todos los diezmos y primicias: como resultado de ello las catedrales perdían la base misma de su subsistencia y de su influencia económica decimonónica, dando como resultado la reducción de salarios de los empleados de las instituciones eclesiásticas o la supresión de puestos musicales. Así, por ejemplo, el artículo 4으 del mencionado decreto decía lo siguiente:

Para indemnizar a los seculares partícipes de diezmos se aplicarán todos los bienes raíces rústicos y urbanos, censos, foros, rentas y derechos que poseen el clero y las fábricas de las iglesias; gozarán de la indemnización las personas y corporaciones que posean rentas en grano o dinero, a cuya satisfacción estén obligados los diezmos; y en cuanto a las fincas pertenecientes a prebendas, capellanías o beneficios de patronato pasivo de sangre, muertos los actuales poseedores

15 Decreto de las Cortes Generales (1 de octubre de 1820): «Las Cortes, después de haber observado todas las formalidades prescritas por la Constitución, ha decretado lo siguiente: I. Se suprimen todos los monasterios de las Órdenes monacales, los canónigos regulares de San Benito, de la Congregación Claustral Tarraconense y Cesaraugustana, los de San Agustín y los Premostratenses; los conventos y colegios de las Órdenes Militares de Santiago, Calatrava, Alcántara y Montesa; los de San Juan de Jerusalén, los de San Juan de Dios y de Betlehemitas, y todos los demás de hospitalarios de cualquier clase, y Hospitalarios. II. Para preservar la permanencia del culto divino en algunos santuarios célebres desde los tiempos más remotos, el Gobierno podrá señalar el preciso número de ocho casas, y dejarlas al cargo de los monjes que tenga por conveniente; pero con sujeción al ordinario respectivo y al prelado superior local que eligieren los mismos, y con prohibición de dar hábitos y profesar novicios...» (citado en Campos y Fernández de Sevilla 2007: 13).

16 Los inventarios se efectuaron según una clasificación de cinco apartados: 1. Casas y edificios en propiedad. 2. Títulos de fincas, censos, foros, diezmos y prestaciones de todas clases. 3. Bienes muebles y efectos. 4. Archivo, bibliotecas, pinturas, etc. 5. Ornamentos, vasos sagrados y objetos destinados al culto. 
deben volver a sus respectivas familias (citado en López Calo 2012: 575).

Pero, sin duda, la gran obra desamortizadora fue la llevada a cabo por Juan Álvarez Mendizábal, ministro de Hacienda y posterior jefe de gobierno interino entre 1835 y 1836. Según Real decreto de 11 de octubre de 1835 se suprimían la totalidad de los monasterios de órdenes monacales y los demás regulares, una medida que reproducía el contenido de los decretos desamortizadores de anteriores épocas liberales. Por su parte, el Real decreto de 19 de febrero de 1836 consagraba que los bienes y rentas de los conventos y monasterios suprimidos serían vendidos con el fin de disminuir la deuda pública del Estado o pago de sus réditos si bien se exceptuaban «los edificios que el Gobierno destine para el servicio público o para conservar monumentos de las artes o para honrar la memoria de hazañas nacionales». ${ }^{17}$ En total, más de 900 conventos españoles se vieron afectados por estas medidas y solo en las provincias de Madrid y Toledo, alrededor de 1940 religiosos fueron expulsados de los aproximadamente 123 conventos a los que se aplicó la legislación desamortizadora. Al no poseer la consideración de bienes de interés artístico, los archivos de música, órganos, libros de coro, y otros objetos relacionados con el arte de los sonidos no gozaron de la protección necesaria para su preservación (Myers 2007: 93).

La situación originada por la ley de la «Reforma y Arreglo del coro» de 1837 así como la supresión del diezmo según Real decreto de 29 de julio de 1837, por el que «todas las propiedades del clero secular en cualesquiera clases de predios, derechos y acciones que consistan, de cualquier origen y nombre que sean, y con cualquiera aplicación o destino con que hayan sido donadas, compradas o adquiridas $»^{18}$

17 Real Decreto de la Reina Gobernadora Doña Mạ Cristina de Borbón (19 de febrero de 1836): "Atendiendo a la necesidad y conveniencia de disminuir la Deuda pública consolidada, y de entregar al interés individual la masa de bienes raíces que habían venido á ser propiedad de la nación, a fin de que la agricultura y el comercio saquen de ellos las ventajas que no podrían conseguirse por entero en su actual estado, o que se demorarían con notable detrimento de la riqueza nacional, otro tanto tiempo como se tardara en proceder a su venta... he venido en decretar los siguiente: I. Quedan declarados en venta desde ahora todos los bienes raíces de cualquiera clase que hubiesen pertenecido á las comunidades y corporaciones religiosas extinguidas, y los demás que hubiesen sido adjudicados á la Nación por cualquier título ó motivo, y también todos los que en adelante lo fuesen desde el acto de su adjudicación. II. Se exceptúan de esta medida general los edificios que el Gobierno destine para el servicio público o para conservar monumentos de las artes o para honrar la memoria de hazañas nacionales» (citado en Campos y Fernández de Sevilla 2007: 14-15).

18 Real Decreto de la Reina Gobernadora Doña M. a Cristina de Borbón (29 de julio de 1837) «Las Cortes, en uso de sus facultades, han decretado lo siguiente: I. Se suprimen la contribución de diezmos y primicias y todas las prestaciones emanadas de los mismos. II. Todas las propiedades del clero secular en cualesquiera clases de predios, derechos y acciones que consistan, de cualquier origen y nombre que sean, y con cualquiera aplicación o destino con que hayan sido donadas, compradas o adquiridas, se adjudican a la nación, convirtiéndose en bienes nacionales... VI. El producto total de estos bienes servirá en parte de pago del presupuesto de la dotación del clero y entrará en cuenta de su haber. VII. El déficit hasta el completo de la dotación del clero y los gastos del culto se suplirá por un repartimiento, que se hará en la nación con el nombre de contribución del culto, al cual están sujetos en proporción a sus haberes todos los contribuyentes a las demás cargas de Estado...» (citado en Campos y Fernández de Sevilla 2007: 17). pasaban a convertirse en propiedad estatal, supuso para numerosas capillas musicales una reducción drástica de sus efectivos y de sus actividades, una rebaja considerable en los salarios de los músicos o en otros casos, la práctica desaparición de algunas capillas.

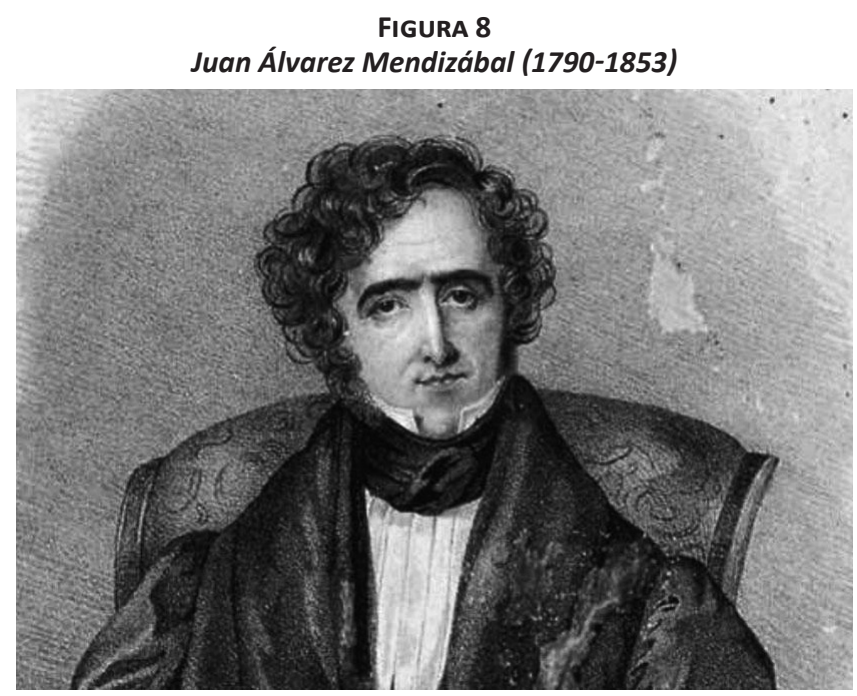

Fuente:Diccionariobiográficoelectrónico.http://dbe.rah.es/biografias/ 9385/juan-de-dios-alvarez-mendez

La Ley Desamortizadora de 1855 del ministro de Hacienda, Pascual Madoz, ${ }^{19}$ afectó a los bienes municipales, del clero, instrucción pública, beneficencia y de la corona y estuvo vigente hasta 1924 con tres fases: 1855-1856, 18581897 y $1896-1924$. Por lo que se refiere a la primera fase, la más efectiva e importante, aunque solo estuviera vigente un año, terminó de desamortizar los bienes de origen eclesiástico. Según Germán Rueda (1996: 66), «la desamortización que continuaba a la de Mendizábal y Espartero se podía dar por concluida, aunque se siguieran vendiendo fincas desde 1861, si bien con un acuerdo previo».

19 Ley General de Desamortización Civil (1 de mayo de 1855): «I. Se declaran en estado de venta, con arreglo a las prescripciones de la presente Ley, y sin perjuicio de las cargas y servidumbres a que legítimamente estén sujetos, todos los predios rústicos y urbanos, censos y foros pertenecientes: Al Estado, al clero, a las Órdenes Militares de Santiago, Alcántara, Calatrava, Montesa y San Juan de Jerusalén, a Cofradías, Obras pías, Santuarios, al secuestro del ex-Infante Don Carlos, a los propios y comunes de los pueblos, a la beneficencia, a la instrucción pública. $Y$ a cualesquiera otros pertenecientes a manos muertas, ya estén o no mandados vender por leyes anteriores. II. Exceptúanse de los dispuesto en el artículo anterior: Los edificios destinados, o que el Gobierno destinare al servicio público, los edificios que ocupan hoy los establecimientos de beneficencia e instrucción, el palacio o morada de los M. RR. Arzobispos y RR. Obispos, y las rectorías o casas destinadas para habitación de los curas párrocos, con los huertos o jardines a ellas anejos, las huertas y jardines pertenecientes al instituto de las Escuelas Pías, los bienes de capellanías eclesiásticas destinadas a la instrucción pública, durante la vida de sus actuales poseedores, los montes y bosques cuya venta no crea oportuna el Gobierno, las minas de Almadén, las salinas, los terrenos que hoy son de aprovechamiento común, previa declaración de serlo..., y por último cualquier edificio o finca cuya venta no crea oportuna el Gobierno por razones graves. III. Se procederá a la enajenación de todos y cada uno de los bienes mandados vender por esta Ley, sacando a pública licitación las fincas o sus suertes a medida que lo reclamen los compradores, y no habiendo reclamación, según lo disponga el Gobierno...» (citado en Campos y Fernández de Sevilla 2007: 25-26). 


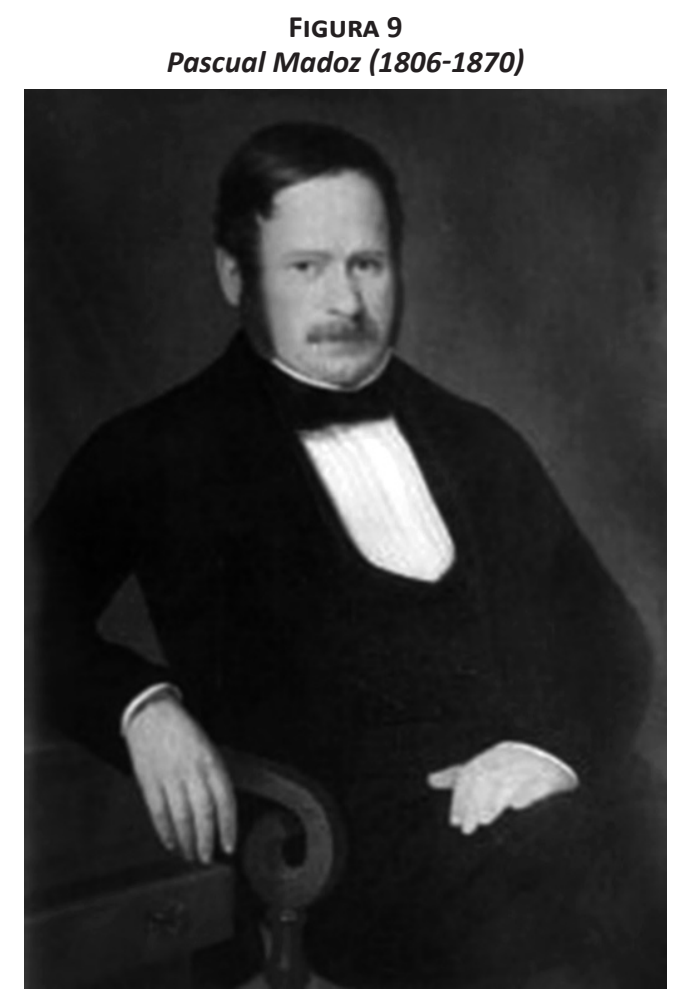

Fuente:Vigopedia.com.https://vigohistoria.files.wordpress.com/2013/ 05/pascual-madoz.jpg

\section{El Concordato DE 1851}

La firma del Concordato el 16 de marzo de 1851 por Isabel II y Pío IX, conlleva una relativa reconciliación de ambas partes, pero no soluciona los problemas de la Iglesia española. Los principales acuerdos de dicho Concordato relacionados con la música pueden resumirse de la siguiente manera: el Estado destinaba, como compensación por la incautación anterior de los bienes eclesiásticos, una cantidad determinada para el mantenimiento del culto y otra para los sueldos de las personas al servicio de las instituciones eclesiásticas: aunque se mantenía la categoría de los canónigos, su número se redujo y a cada canonjía se asignó un modesto sueldo; se cambió la categoría de racioneros por la de beneficiados; el número de los beneficiados músicos también quedó especificado según la catedral: así por ejemplo, las metropolitanas solo podían conservar seis plazas (maestro de capilla, organista, sochantre, contralto, tenor y bajo), las sufragáneas podían llegar hasta cuatro y en las colegiatas se redujeron a dos. La provisión de las plazas debía recaer única y exclusivamente en clérigos (López-Calo 1999a: 444-445).

A pesar de la firma del concordato, no siempre se cumplieron los acuerdos económicos: o bien no llegaban los fondos prometidos por el gobierno o llegaban tarde a las respectivas iglesias debido a la burocracia creada al efecto o porque en última instancia, se dependía de las decisiones de las juntas locales o jefes políticos. Como consecuencia de todo ello, los cabildos se vieron en la necesidad de disminuir los efectivos musicales de las capillas, quedando apenas los imprescindibles para atender mínimamente el culto; algunas instituciones eclesiásticas, como es el caso de la colegiata de Talavera de la Reina (reconvertida en iglesia parroquial debido a la reordenación del mapa religioso español), se vieron obligadas a suprimir la capilla de música. ${ }^{20}$

FIGURA 10

Segunda edición del Concordato de 1851

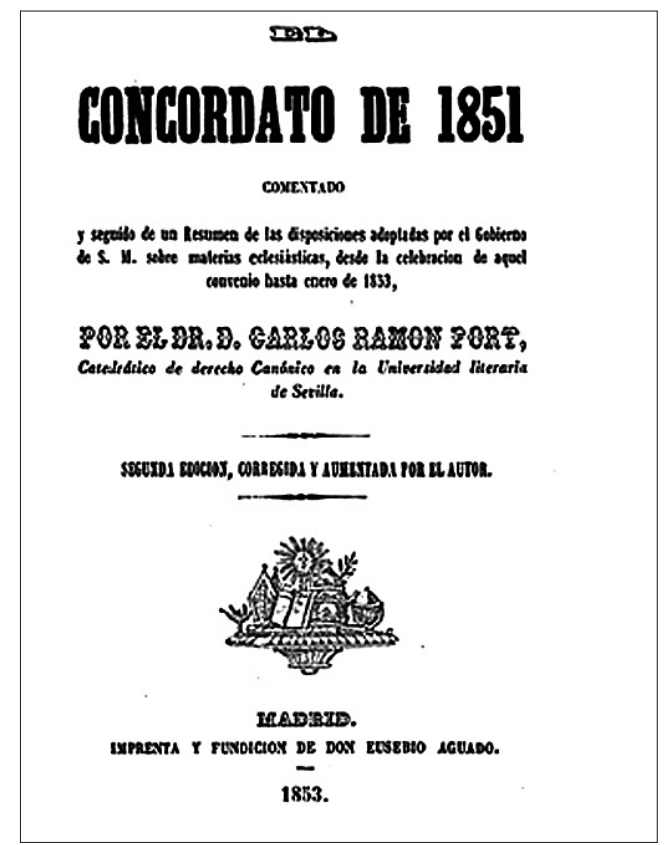

Fuente: Ecured. https://www.ecured.cu/Concordato_de_1851\#/media/ File:Concordato_1851.jpg

Pronto se alzaron las voces contra esta normativa que perjudicaba claramente la música eclesiástica española. Hilarión Eslava, en un artículo publicado en 1855 en la Gaceta Musical de Madrid, señalaba la pobre composición de los coros catedralicios y protesta por la obligación de que sean clérigos los músicos de las catedrales, subrayando la falta de equidad en la asignación de las rentas, al igualar a todos los beneficiados de música:

La circunstancia de exigirse por el Concordato que sean clérigos los profesores de las catedrales dificulta más y más la organización de sus capillas. Además, las rentas que en él se asignan a dichos profesores no guardan proporción alguna equitativa. El maestro de capilla que, además de dirigir y componer obras, está encargado de la enseñanza de los niños de coro, goza la misma dotación que el contralto y tenor, cuyas obligaciones se limitan únicamente a cantar su respectivo papel. Esto no es justo, por razones que nadie ignora (Eslava 1855: 17-18).

En opinión de Eslava, la decadencia de la música religiosa es consecuencia de los acuerdos de 1851 entre Iglesia y Estado, criticando que las plazas convocadas no se cubran por la escasez de aspirantes con suficiente preparación:

Cuán poco ha sido esta materia, lo prueban los tristes resultados que tocamos. Una gran porción de iglesias catedrales han expedido edictos para varias plazas que se hallan vacantes, y no se han presentado opositores o se han provisto de cualquier modo. En otras, sin embargo de haber vacantes, no se proveen por saberse con certeza que no hay sujetos dignos de ocuparlas, si han de ser sacerdotes (Eslava 1855: 18).

20 Véase al respecto Capdepón 2012a, 2013a, 2013b, 2016a y 2017. 
FIGURA 11

Gaceta Musical de Madrid (1855)

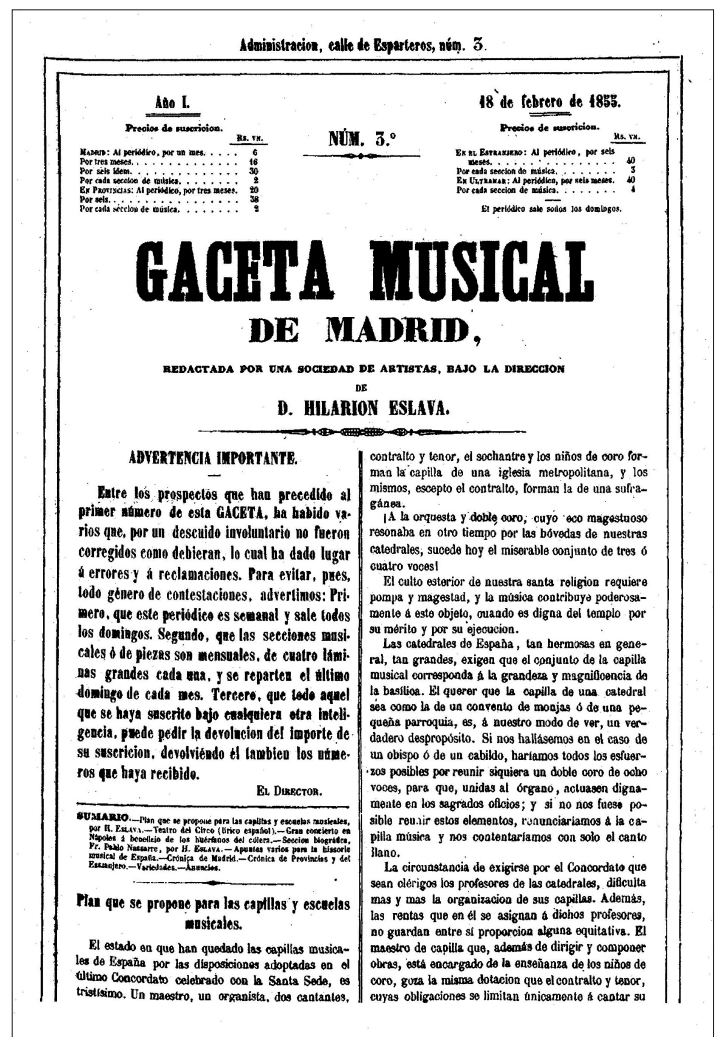

Fuente: hemerotecadigital.bne.es. http://hemerotecadigital.bne.es/ issue.vm?id=0003895173\&search=\&lang=es

En definitiva, el Concordato va a significar una crisis sin precedentes en la música eclesiástica española, principal fuente de trabajo durante siglos para nuestros músicos: apenas se cubrían las necesidades e incluso algunas instituciones llegaron a suprimir las capillas musicales como consecuencia de la falta de financiación.

\section{PROYECTOS DE REFORMA DE LA MÚSICA SACRA EN ESPAÑA ${ }^{21}$ Introducción: el cecilianismo}

El panorama musical español del siglo XIX no fue insensible a las corrientes reformistas y neohistoricistas que tenían como objetivo la reforma de la música religiosa, como es el caso del cecilianismo alemán, surgido en la segunda mitad del siglo XIX, tendente a la restauración de la pureza en la música religiosa. Tres vertientes fundamentales presenta esta corriente: la restauración del auténtico canto gregoriano, la recuperación de la polifonía clásica del siglo XVI y la creación de un nuevo estilo religioso de composición musical.

Los inicios del cecilianismo ${ }^{22}$ se remontan al movimiento iniciado por Kaspar Ett, organista de la corte de San Miguel en Múnich desde 1815, que inició la recuperación e interpretación de música histórica del Renacimiento, en especial de

21 María Antonia Virgili ha sido una de las investigadoras que con mayor detenimiento ha profundizado en esta temática $(1995,2004 a$, 2004 b y 2010).

22 Veáse al respecto Garbini 2009: 317 y s. y López-Calo 1999b: 459 y ss. la Escuela romana. Sin embargo, Ett no pretendía extender la influencia de su movimiento fuera del marco local de Múnich. ${ }^{23}$ Quien sí puede considerarse como fundador del cecilianismo es Karl Proske (1794-1861), canónigo de la Colegiata Alte Kapelle de Ratisbona desde 1830: a instancias del obispo de Ratisbona, Proske preparó un memorial sobre la reforma de la música sagrada de las catedrales, memorial que fue aprobado por el rey Luis I de Baviera, el cual asimismo patrocinó varios viajes de Proske a Italia con el fin de recopilar obras musicales entre los siglos XV y XVIII. Posteriormente, en 1838 Luis I decretó que en la catedral de Ratisbona solo se interpretara música coral a capella (López-Calo 2006: 582-583).

FIGURA 12

Kaspar Ett (1788-1847)

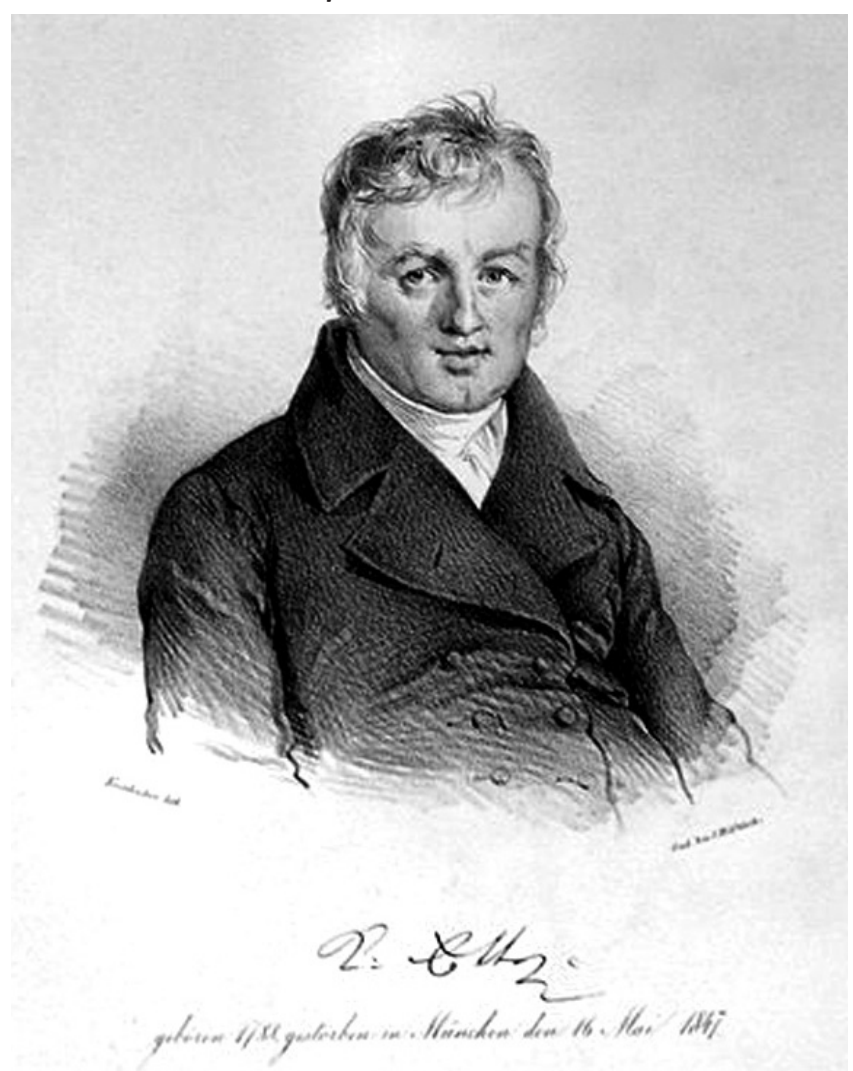

Fuente: Wikipedia. https://es.wikipedia.org/wiki/Caspar_Ett\#/media/ Archivo:Caspar_Ett.jpg

La obra restauradora de Proske fue continuada por Franz Xaver Witt, quien fundó en 1866 una revista titulada Fliegende Blätter für Katholische Kirchenmusik (Hojas volantes para la música católica eclesiástica), un proyecto más ambicioso que intenta superar el marco regional alemán de sus predecesores. Dos años después editaba una nueva revista, cuyo título deja entrever con claridad los objetivos perseguidos por Witt: Música Sagrada. Contribuciones para la reforma y promoción de la música religiosa entre los católicos. A este esfuerzo editorial se sumó la creación de una "Asociación Germánica de Santa Cecilia», que fue aprobada en 1868 en Bamberg, a la cual el papa Pío IX concedió el reconocimiento pontificio en 1870 .

${ }^{23}$ Sobre este músico véase el estudio clásico de Ursprung 1924 y el de Morrison 1997. 
FIGURA 13

Franz Xaver Witt (1834-1888)

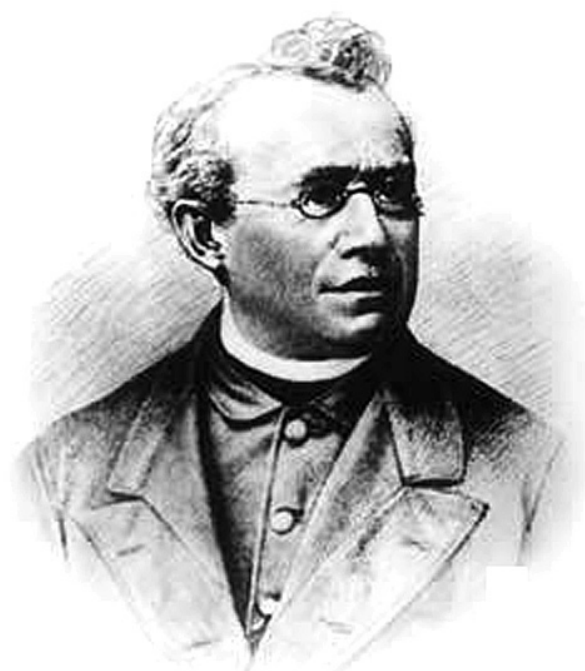

Fuente: Wikipedia. https://en.wikipedia.org/wiki/Franz_Xaver_Witt\#/ media/File:FXWitt.jpg <Fig. 13>

El sacerdote Franz Xaver Haberl y el editor Friedrich Pustet desempeñaron un papel de gran relevancia en el asentamiento y propagación de los ideales del cecilianiasmo. Como heredero de la obra pionera de Proske y Witt, Haberl transcribió y editó innumerables obras polifónicas, siendo además el artífice en 1874 de la Escuela de Música Sagrada de Ratisbona. Por su parte Pustet fundó en 1826 una editorial con su nombre, especializada en la publicación de obras religiosas y se convirtió en el principal vehículo de difusión de las aportaciones de los primeros cecilianistas, entre las que destaca Magister Choralis (1864), de Haberl.

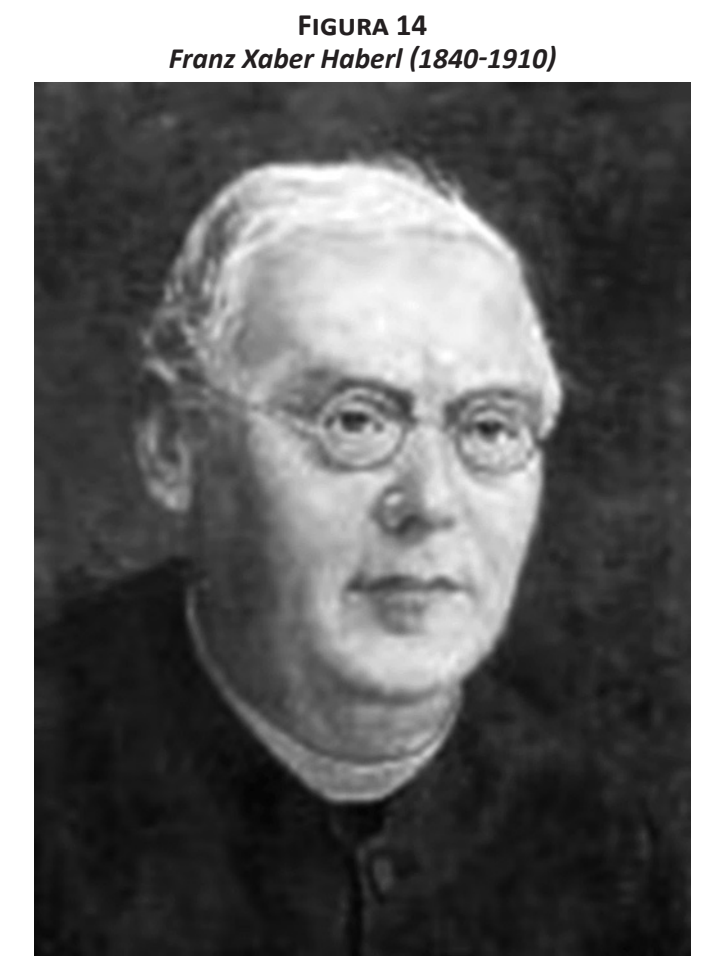

Fuente: Wikipedia. https://es.wikipedia.org/wiki/Franz_Xaver_Haberl\#/ media/Archivo:FXHaberl.jpg
FIGURA 15

Friedrich Pustet (1798-1882)

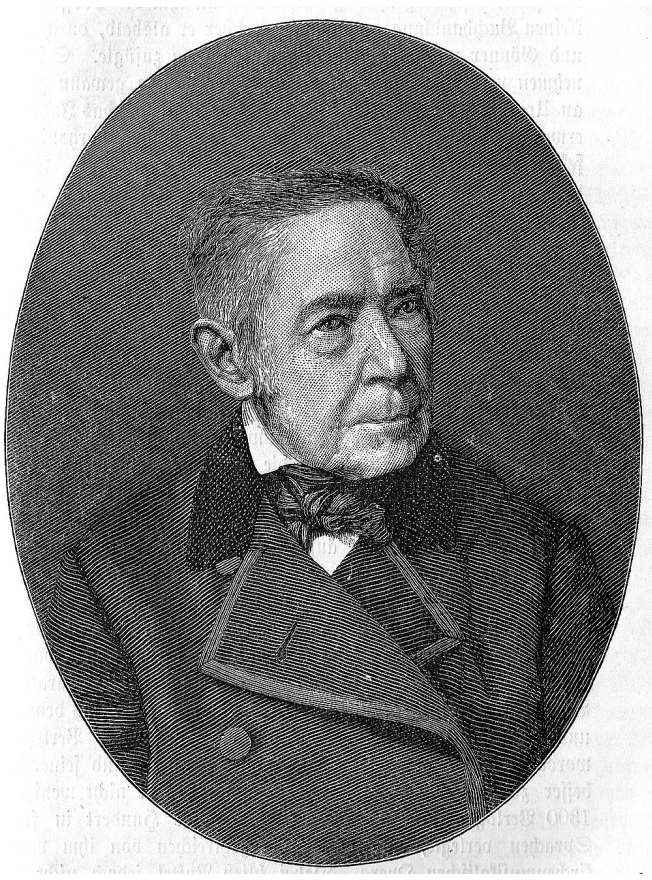

Fuente: Wikipedia. https://de.wikipedia.org/wiki/Friedrich_Pustet_ KG\#/media/Datei:Friedrich_Pustet.jpg

El movimiento cecilianista se extendió a otros países como Estados Unidos o Irlanda pero el país que mostró mayor entusiasmo ante la iniciativa alemana fue Italia gracias a Guerrino Amelli, Giuseppe Terrabugio o Lorenzo Perosi, aunque la actividad de este último se adentra ya en el siglo XX.

\section{Las reformas de Eslava}

Hilarión Eslava fue uno de los primeros compositores españoles que intentó adaptarse a la nueva situación surgida en Europa con la aparición de la corriente cecilianista.

La primera iniciativa reformista de Eslava se remonta al año 1852 cuando en marzo de aquel año funda la «Asociación de la Lira Sacro Hispana», cuyo principal objetivo consistía en «la publicación de una colección completa de las mejores obras de música religiosa, compuestas por los más acreditados maestros españoles, tanto antiguos como modernos» (Eslava 1860: 1). A continuación emprendió un largo viaje por Europa con la finalidad de estudiar y copiar obras españolas conservadas en los archivos y bibliotecas de los países que tenía previsto visitar (Francia, Alemania y Austria) pero al mismo tiempo aprovechó la ocasión para informarse sobre los diferentes movimientos europeos que propugnaban la reforma de la música religiosa en lo referente a la recuperación de obras históricas (López-Calo 2006: 596). El resultado de esta primera iniciativa fue la publicación de una amplia selección de la polifonía clásica española más destacada de los siglos XVI y XVII bajo el título de Lira Sacro Hispana (Eslava 1852-1860). En opinión de Samuel Rubio (1978: 153), "se trata de una empresa que hoy mismo nos asustaría; que de hecho no se ha vuelto a repetir, aunque su necesidad es bien patente y apremiante; que supone un tesón, una fuerza de voluntad y una constancia para no desmayar ante el cúmulo de dificultades que tuvo que vencer Eslava, rayando en lo milagroso». 
FIGURA 16

Lira Sacro Hispana (1852-1860), de Eslava

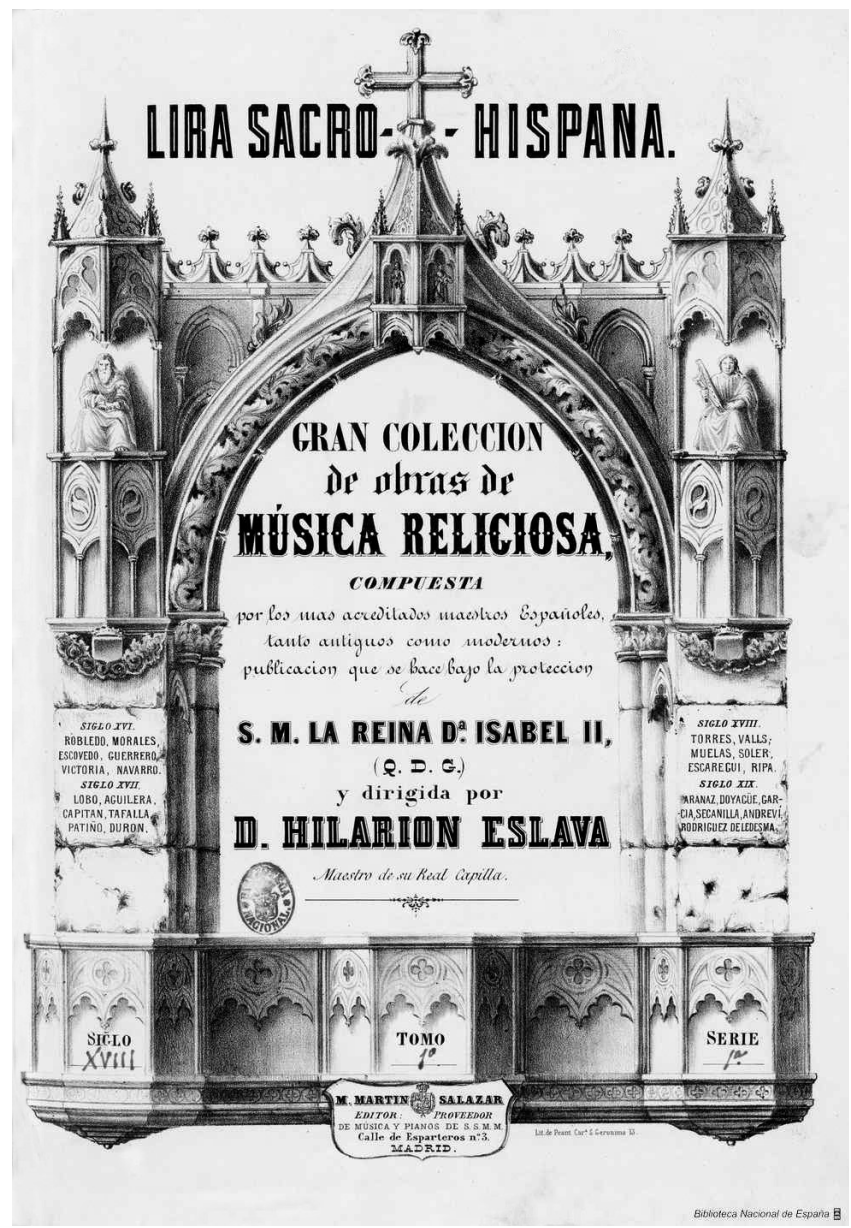

Fuente: Omnia.ie. http://www.omnia.ie/index.php?navigation function $=2 \&$ navigation_item $=\% 2 F 2022717 \% 2 F b n e s e a r c h \_d e t a l l e \_$ bdh0000007954\&repid=1

Pero su iniciativa no se limitó al ámbito vocal: al año siguiente, en 1853, acometió una nueva antología de música organística española. El fin de esta nueva publicación, titulada Museo orgánico español, además de rebatir las negativas opiniones vertidas en Europa sobre el órgano español contemporáneo, tal como vimos anteriormente, consistía en la mejora de este campo de la música religiosa española, tal como lo expone el propio Eslava en el prefacio de esta publicación:

El objeto de la obra que ofrezco a mis comprofesores es de la más alta importancia: constituir el verdadero género orgánico-religioso, establecer las bases y reglas que para él deben regir, dar un gran número de piezas compuestas con sujeción a ellas, esclarecer la historia de los organistas españoles, y proponer todos los medios más conducentes para mejorar este ramo, que es uno de los más importantes del arte musical. He aquí los fines que en esta publicación me propongo (Eslava 1853: prólogo).

Una segunda iniciativa reformista de Eslava fue propuesta en un artículo publicado en la revista Gaceta Musical de Madrid, fundada por él mismo. Dicho artículo llevaba como título «Plan que se propone para las capillas y escuelas musicales» (Eslava 1855). Para remediar el estado "tristísimo» de la música religiosa española en general y de las capillas musicales españolas en particular, Eslava propuso establecer escuelas de música en todas las catedrales, las cuales dependerían del Conservatorio de Madrid y cuyos profesores serían los mismos músicos de las catedrales, insistiendo en que debía suprimirse la obligatoriedad de que los mencionados músicos fueran clérigos. Si ello se lograra, «dentro de pocos años tendrán muchas iglesias una capilla digna del culto religioso, y el Conservatorio nacional una porción de pequeñas escuelas sucursales en las provincias en que abundan las buenas disposiciones para el arte musical» (Eslava 1855: 18). Concretamente, Eslava enumera ocho medidas que pueden resumirse de la siguiente manera:

1. En cada ciudad donde esté presente una catedral, «se establecerá una escuela de solfeo y canto por ahora, y podrá mas adelante comprender otros ramos del arte».

2. Dichas escuelas dependerían del Conservatorio Nacional de Madrid, el cual «determinará el plan de estudios que en ellas deban seguirse».

3. Los protectores de tales escuelas serán las Sociedades de Amigos del País, las diputaciones provinciales o los ayuntamientos, todos los cuales deben proporcionar los locales y los materiales necesarios.

4. El número de alumnos en cada escuela se elevará a 18 como mínimo (12 alumnos y 6 alumnas), «siendo preferidos en igualdad de circunstancias los más pobres y desvalidos».

5. Los alumnos varones, una vez que estén suficientemente formados, «tendrán obligación de asistir en los días de primera clase a la catedral, y desempeñar la parte que les designe el maestro de capilla».

6. Aunque el responsable principal de la enseñanza será el Maestro de capilla respectivo (con el cargo de subinspector del Conservatorio Nacional de Madrid), sin embargo, las clases recaerán en los miembros de la capilla musical que tengan menor renta y menos obligaciones, es decir, el organista, el contralto y el tenor de cada capilla.

7. Los servicios prestados en estas escuelas por parte del Maestro y de los restantes miembros de las capillas, "se tendrán presentes para la provisión de las plazas que vacaren en el Conservatorio».

8. Las obligaciones a las que se refiere el anterior apartado sexto, "solo se entienden con los que obtengan en adelante las plazas indicadas con esas mismas obligaciones; pero de ningún modo con aquellos que las obtienen hoy y que entraron sin ellas» (Eslava 1855: 18).

Sigue diciendo el compositor navarro que, con su minucioso plan, la enseñanza musical se habría extendido por toda España y las capillas musicales catedralicias recibirían un "refuerzo poderoso» ya que los alumnos participarían en los actos litúrgicos con intervención musical formando parte de un «segundo coro, cual conviniese para el buen desempeño de las obras que deben ejecutarse en el templo» (Eslava 1855: 18).

A pesar del interés de la propuesta de reforma de la música religiosa y de las positivas implicaciones educativas que hubiera supuesto la implantación de sus ideas, y pese al prestigio que gozaba ya por entonces, el gobierno no respondió al «plan» de Eslava ni sus iniciativas fueron tenidas en cuenta en ningún momento. 
FIGURA 17

Hilarión Eslava (1807-1878)

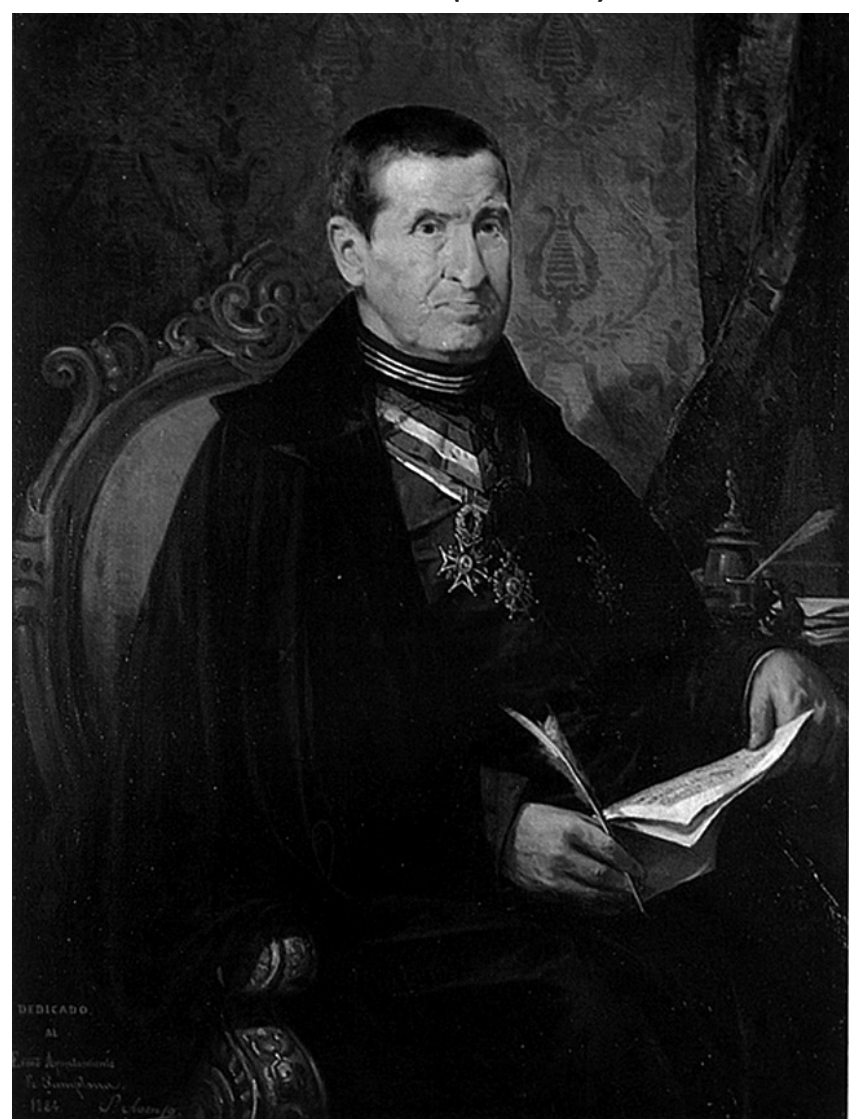

Fuente: Enciclopedianavarra.com. http://www.enciclopedianavarra. com/wp-content/uploads/5191.gen07088002.jpg

\section{La propuesta de Barbieri}

Con motivo de la celebración del Congreso Católico en mayo de 1869, Francisco Asenjo Barbieri tuvo una destacada intervención que fue recogida posteriormente en los números 34 y 35 de la revista La llustración Musical Hispanoamericana: además de realizar un breve recorrido histórico de la música sacra, aborda el estado de decadencia en que se encuentra la música religiosa española de su tiempo, si bien matiza que no cabe aplicar este término a la calidad de la creación de sus contemporáneos en este ámbito:

\begin{abstract}
... no obstante diré que si la decadencia se entiende en cuanto al fondo del arte músico religioso, no sólo no existe tal decadencia, sino que, al contrario, se nota una tendencia filosófica y progresiva, hija del desarrollo de los estudios estéticos. Así vemos que muchos compositores españoles tratan en sus obras de reunir a la expresión de los textos litúrgicos las reminiscencias del estilo del Renacimiento y los adelantos de la armonía y la instrumentación moderna. De esto podrían citarse muchos ejemplos, que evito por evitar personalidades, pero puede asegurarse que si continúa este movimiento, tal vez dentro de pocos años podría España gloriarse de haber hecho una obra meritoria para Dios y para el arte patrio (Casares 1994: 451).
\end{abstract}

Barbieri habla sin embargo de una "real y tristísima decadencia» cuando se refiere a los medios materiales. Critica el compositor madrileño el recurso a los músicos festeros como medio de sustituir a las tradicionales capillas:
Hoy apenas se encuentra una catedral o colegiata que pueda mantener con desahogo el número de cantores o instrumentistas más indispensables, no digo para fiestas solemnes, pero ni aún para el servicio diario. En el siglo anterior, una ración o un medio-beneficio representaba económicamente más que hoy una canonjía, y esto era un estímulo poderoso para que se inclinaran al estado eclesiástico los buenos artistas que hoy buscan su fortuna fuera de la iglesia. ¿Cómo, pues, ha de brillar la música religiosa con tan escasos elementos de ejecución?... Así la vemos ejercida principalmente por festeros seglares, que con sus capillas acuden al servicio del templo cuidándose de hacer un estrépito que sea grato a la cofradía que los paga, no sin regatearles previamente un tenor o un violín, como si fueran artículos de consumo (Casares 1994: 451).

Para remediar tal situación, en opinión de Barbieri la solución reside en potenciar la figura crucial del maestro de capilla, pero pone en tela de juicio que, como resultado de la aplicación del Concordato de 1851, los maestros de capiIla tengan la obligación de ser clérigos. Aduce como prueba de la incongruencia de esta medida que en el momento de pronunciar su discurso (1869), se hallaban vacantes 23 magisterios de capilla, plazas que sí estaban cubiertas en tiempos anteriores por «muy buenos maestros, los cuales no solo daban esplendor al culto con sus composiciones, sino que enseñaban la música a los niños de coro, formándose una escolanía en cada catedral, donde se educaban excelentes profesores cantantes e instrumentistas, utilísimos para el servicio divino y para la conservación y desarrollo de la música religiosa» (Casares 1994: 451). Critica Barbieri la escasez del sueldo percibido por los maestros de capilla (lo llega a comparar con el salario de un portero de cualquier Ministerio). Si por el contrario se derogase la condición de pertenecer al estado eclesiástico para ejercer el cargo de maestro de capilla, este, en caso de ser seglar, podría completar su sueldo mediante otras vías. Concluye Barbieri diciendo que, dada la escasez de sacerdotes con dotes para la composición musical, los puestos de maestro de capilla recaen en personas con poca o nula capacidad que no son dignos herederos de los grandes maestros del pasado. Concluye Barbieri afirmando que, para evitar el estado de lamentable decadencia en que se encuentra

FIGURA 18

Francisco Asenjo Barbieri (1823-1894)

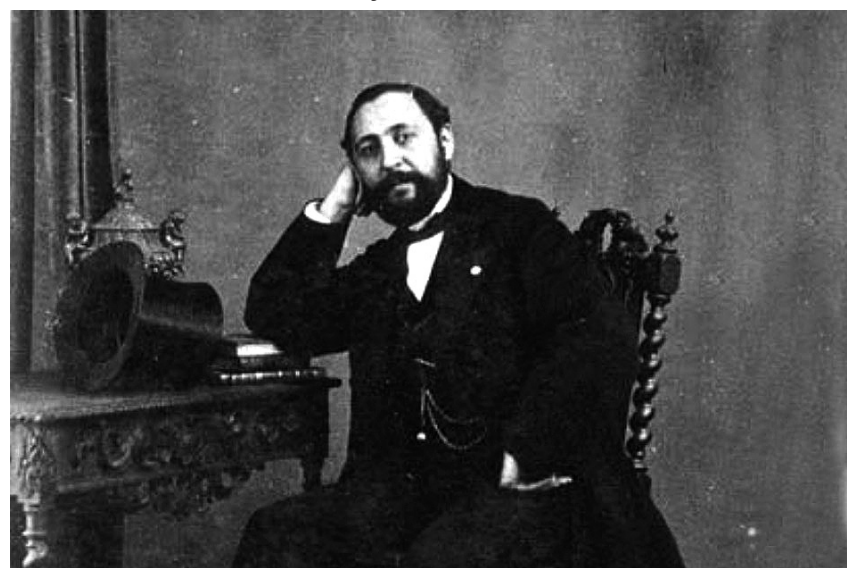

Fuente: Diccionario biográfico electrónico. http://dbe.rah.es/biografias /7805/francisco-de-asis-esteban-asenjo-barbieri 
la música española religiosa de su tiempo, el papa debería derogar la cláusula del Concordato que prohíbe a los seglares acceder al magisterio de capilla con el objetivo final de que tal función la ejerza el músico mejor dotado, independientemente de su estado (Casares 1994: 452).

\section{Las iniciativas de Felipe Pedrell}

No podría entenderse la difusión del mencionado Motu Proprio en España sin tener en cuenta los esfuerzos anteriores llevados a cabo por Felipe Pedre $\|^{24}$ en el ámbito de la música polifónica, que se traducirán en varias facetas: destaca en primer lugar la publicación periódica de la colección Salterio Sacro Hispano («publicación continua de música religiosa»), de corta trayectoria y cuyo título demuestra claramente la posible influencia del modelo establecido por Eslava en su Lira Sacro Hispana. Sus inicios se remontan a 1882 como fruto de la preocupación del compositor por la dignificación de la música religiosa. Sin embargo, desde el principio, el propio compositor no estaba convencido de la viabilidad de la colección ya que, dada la situación que vivía la música española en aquella época, no pudo acometer su idea primitiva al fundar dicha colección, que consistía en la recuperación de la polifonía litúrgica española, restaurando su auténtico valor, tal como ha señalado acertadamente Bonastre (2001).

FIGURA 19

Felipe Pedrell (1841-1922)

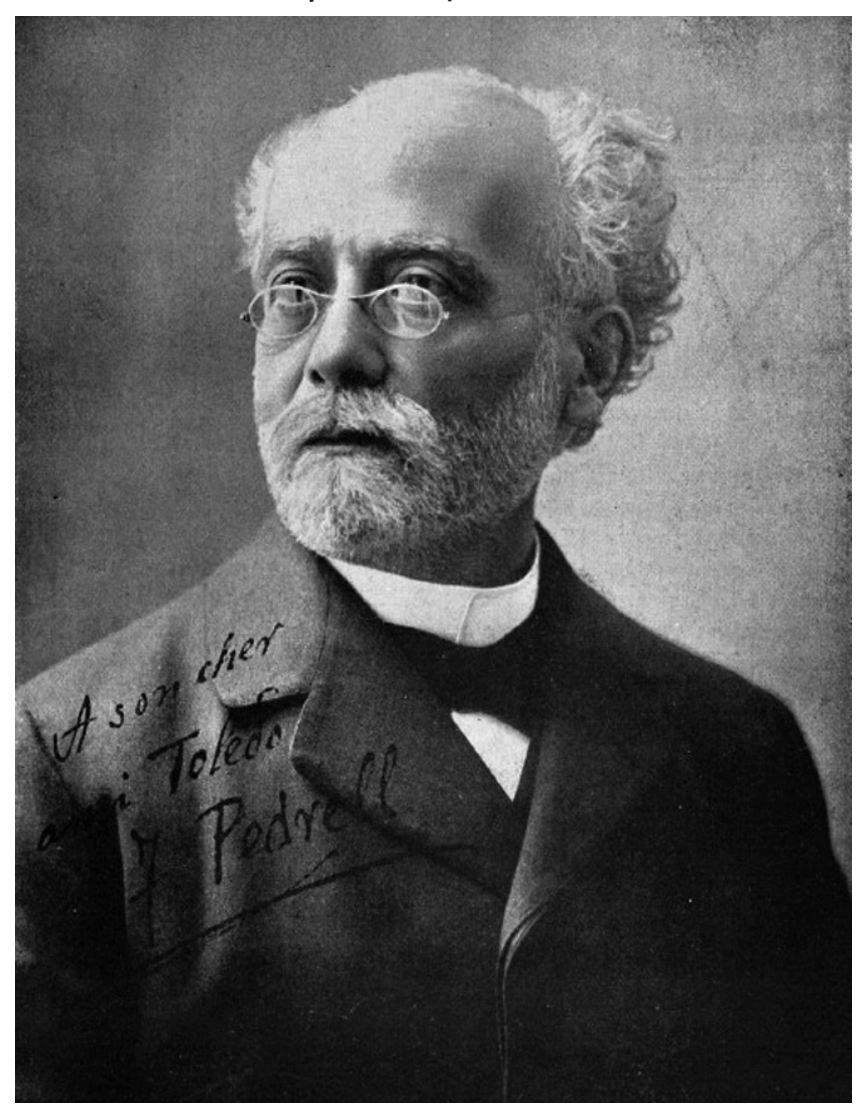

Fuente: Wikipedia. https://es.wikipedia.org/wiki/Felipe_Pedrell\#/ media/Archivo:Felipe_Pedrell_01.jpg

${ }^{24}$ Una de las primeras visiones de conjunto es ofrecida en Bonastre 1972.
Otra iniciativa de gran trascendencia fue la publicación entre 1894 y 1896 de la colección Hispaniae Schola Musica Sacra, gracias a la cual Pedrell dio a conocer los hitos más importantes del siglo de oro de la polifonía española, incluyendo no solo la transcripción de las obras musicales sino también un profundo estudio histórico-musical; esta obra incluía obras y estudios sobre compositores tan emblemáticos para nuestra historia musical como Francisco Guerrero, Cristóbal de Morales, Antonio de Cabezón, Tomás Luis de Victoria, Ginés Pérez y Tomás de Santa María, entre otros, y contribuyó sin duda al notable prestigio científico que alcanzó Pedrell en toda Europa. En 1896 la colección se vio interrumpida porque la casa editora de Hispaniae Schola Musica Sacra, J. B. Pujol y Cía, fue comprada por la editorial alemana Breitkopf und Härtel de Leipzig y, si en un primer momento parecía que la colección tendría una continuidad, posteriormente los responsables de dicha editorial optaron por editar la Opera Omnia de Tomás Luis de Victoria. Pese a la decepción que supuso la interrupción de la colección Hispaniae Schola Musica Sacra, Pedrell no cejó en su empeño reformista y al año siguiente fundó y dirigió la revista La Música Religiosa en España (1897-1899).

Como ya dijimos, la editorial Breitkopf und Härtel había propuesto a Pedrell la magna obra de editar la obra com-

Figura 20

Primer volumen de la Opera omnia de Victoria

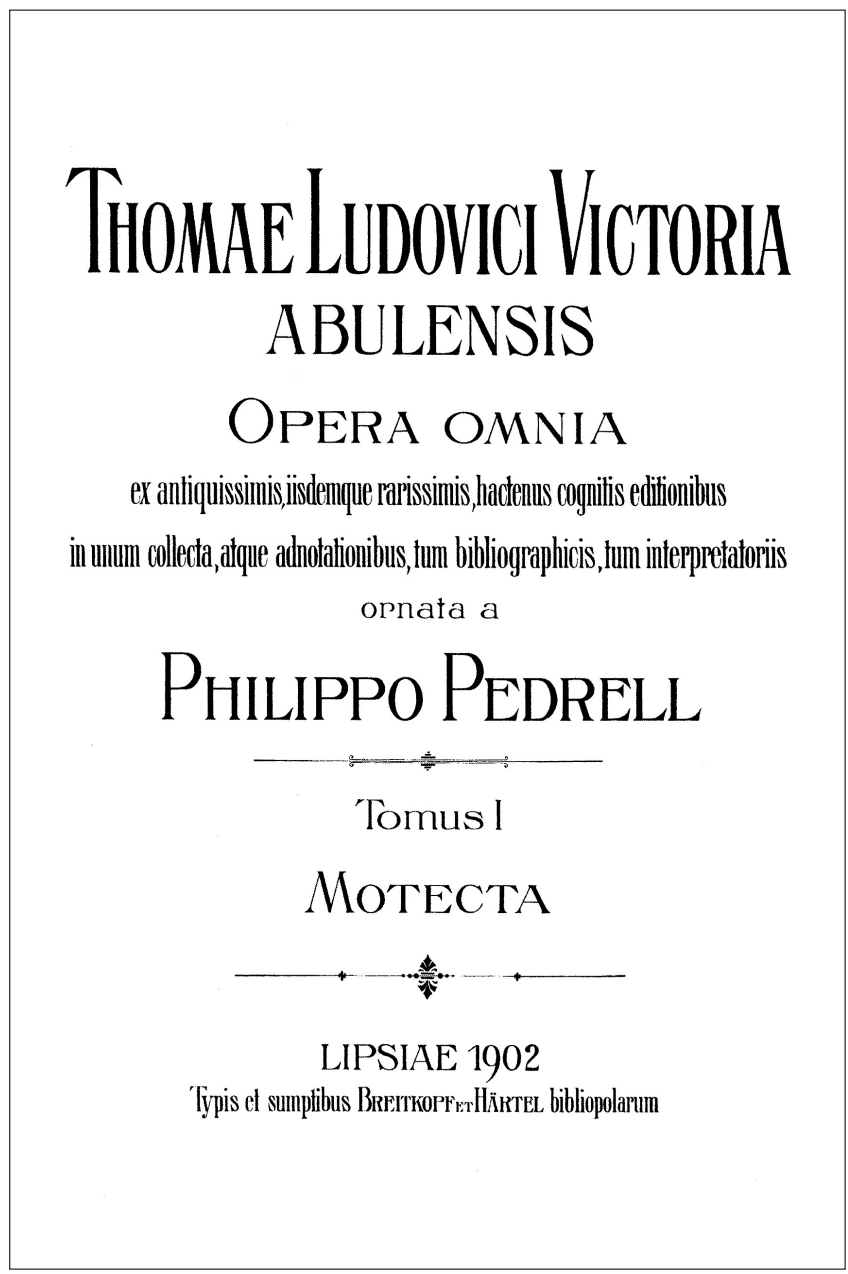

Fuente: GoogleBooks. https://books.google.es/books/about/Thomae_ Ludovici_Victoria_Abulensis_Opera.html?id=Oro4AQAAMAAJ\&redir_esc $=\bar{y}$ 
Como ya dijimos, la editorial Breitkopf und Härtel había propuesto a Pedrell la magna obra de editar la obra completa de Tomás Luis de Victoria en ocho volúmenes, ${ }^{25}$ labor efectuada entre 1902 y 1913, que representó para Pedrell el mayor reconocimiento científico a nivel internacional, demostrando su dominio de la técnicas paleográficas así como sus profundos conocimientos históricos y musicales sobre el siglo XVI español y revelando su «verdadera talla de musicólogo excepcional» (Bonastre 2001: 554).

Por último, no puede soslayarse la innegable influencia que ejerció Pedrell en la difusión y recepción favorable del Motu Propio en la España de los primeros años del siglo XX, como lo atestigua su intento de rescatar el Salterio Sacro Hispano en 1906, iniciativa que tampoco tuvo continuidad en el tiempo, lo cual achacó al editor, a la sazón Vidal Llimona y Boceta, a quien tilda de "corredor de mercadería musical». A pesar de ello, es innegable el éxito de esta segunda etapa, como lo demuestra el hecho de que en muchas catedrales y archivos españoles se conserven un buen número de composiciones pertenecientes a dicha colección (LópezCalo 1991). El prólogo del Salterio Sacro Hispano justifica de la siguiente manera su razón de ser:

Desde que nuestro venerable Pontífice, Su Santidad Pío X, expidió su sapientísimo Decreto para el mejor régimen y gobierno del mundo católico en lo que se refiere al Canto litúrgico y a la música única que debe emplearse en las iglesias, ha sido la preocupación constante de esta Casa y su labor preferente preparar una gran colección de obras debidas a la inspiración de renombrados compositores eminentes maestros españoles, antiguos y modernos, en que se restituyen felizmente el venerable Canto gregoriano y la Música clásica polifónica de la célebre escuela antigua española, según las prescripciones de los cánones y la primitiva disciplina y costumbre de nuestra Santa Iglesia (López-Calo 1991: 174).

En resumidas cuentas, a Pedrell se le consideraba por entonces como el patriarca de la música religiosa española y «el más ardoroso y mejor preparado promotor de la reforma de la música litúrgica», tal como lo define LópezCalo (1999c: 876).

\section{La propuesta de Olmeda}

Fundamental fue asimismo la labor de Federico Olmeda (1865-1909), ${ }^{26}$ maestro de capilla y organista de la catedral de Burgos, uno de cuyos mayores logros -en su calidad de abanderado de la reforma religiosa - consistió en la restauración del canto religioso popular, que viene a certificar la aplicación del nacionalismo a la música religiosa: para ello

25 Se trata de la segunda edición de una Opera Omnia de un compositor español ya que la primera se remonta a 1896 cuando se inició la publicación de la obra completa de Nicolás Ledesma por el editor bilbaíno Dotésio. Sobre Ledesma consúltese asimismo AA. VV. s. f.; Guaza y Guerra 1884b; Esperanza y Sola 1906b; Heine 1997; Rodríguez Suso 1999; Nagore 2000; Elizondo 2002; Flores Pena 2011; De Peque 2012 Capdepón 2012b; Ezquerro 2012 y 2015 . No deja de ser sorprendente que en recientes aportaciones historiográficas sobre el siglo XIX español solo se dedique una línea a uno de los más sobresalientes compositores de música vocal e instrumental, como es el caso de Nicolás Ledesma (Carreras 2018: 433).

26 Sobre la trayectoria de Olmeda, consúltese Palacios 2003. En relación a la importancia de Olmeda en la recuperación del canto gregoriano y su relación con el Motu Proprio, véase Asensio 2004. recopiló melodías de carácter popular con el fin de acercar este tipo de canto al pueblo. Ello está en relación con una de las recomendaciones del Motu Proprio, en el sentido de reformar la música religiosa, favoreciendo su popularización. A ello se refiere el propio Olmeda en su libro Folk-lore de Castilla o Cancionero popular de Burgos cuando afirma lo siguiente:

El estado de la música religiosa es alarmante. Comenzando por la Catedral, en donde generalmente no se cantan más que obras mal presentadas, de compositores de épocas muy decadentes para la música religiosa, como Reyero y Don Plácido García, es decir, folías como diría Feijoo, y concluyendo por el último pueblo, se ve, que en punto a música sagrada, aquí no ha quedado nada de aquella grandiosidad del arte polifónico español del siglo XVI, y apenadas nada de aquellas canciones del estilo del canto gregoriano, que tanto debían abundar a juzgar por las reminiscencias y vestigios que he encontrado en el mismo pueblo por aquí y por allí en mi extensa peregrinación por la provincia. Apenas he hallado algunos ejemplares completos de esta clase. Al ponerme en inteligencia con muchos campesinos de edad muy avanzada, han querido recordar canciones que debían ser preciosísimas, a juzgar por los fragmentos y pormenores que me cantaban; pero como estas canciones han estado en desuso por tan largo tiempo son muy pocos ya los vivientes que las conocen: y lo poco que recuerdan algunos de los más viejos es incompleto y no fidedigno. Con la última generación se puede asegurar que ha bajado a la muda e impenetrable fosa de los muertos un tesoro de canciones sagradas, que hubieran tenido un valor incalculable para el repertorio y restauración del canto gregoriano (Olmeda 1903: 183).

FIgURA 21

Federico Olmeda (1865-1909)

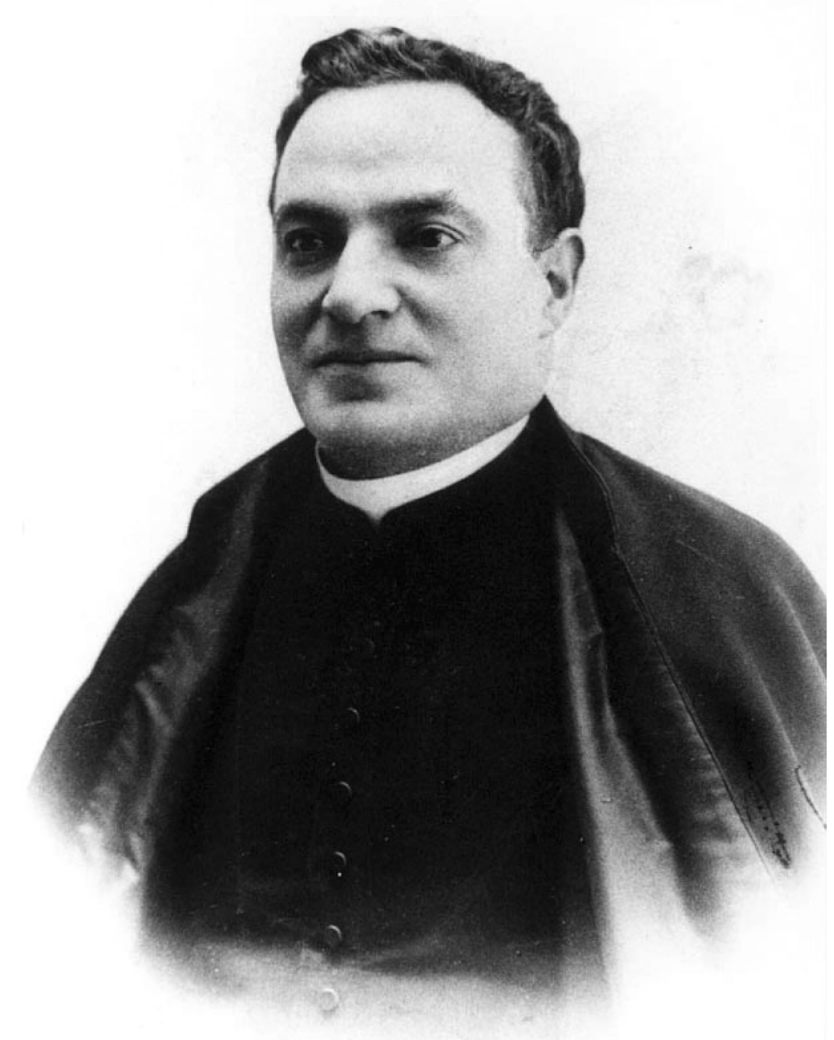

Fuente: Wikipedia. https://es.wikipedia.org/wiki/Federico_Olmeda\#/ media/Archivo:Federico_Olmeda.jpg 
Para concluir este apartado, es necesario distinguir tres elementos importantes en estos y otros intentos reformadores que se suceden en la España de la segunda mitad del siglo XIX y comienzos del XX: la recuperación de la música polifónica clásica, la composición de obras musicales en el nuevo estilo y lo que podría definirse como propuestas teóricas y organizativas, como las protagonizadas por Eslava y Barbieri. La composición de obras musicales en un nuevo estilo, más sobrio y adaptado a la liturgia y a los conceptos que posteriormente Pío X sancionaría con su Motu Proprio de 1903, comienza a aparecer, en un gran número de catedrales españolas, en torno a la mitad del siglo XIX (Casares 1995: 70).

\section{LA RESTAURACIÓN DEL CANTO GREGORIANO}

Por lo que se refiere al canto gregoriano, su restauración auténtica será uno de los principales ejes que vertebre la actividad musical en la segunda mitad del siglo XIX en Europa, y como tal se convertirá posteriormente en centro de atención del decreto papal de Pío X: ello ha de enmarcarse en la tendencia típicamente romántica de buscar una mayor autenticidad, y en el caso concreto de la vida religiosa, en el deseo de imitar la austera vida monástica de la Antigüedad y de la Edad Media. La recuperación del canto gregoriano será llevada a cabo por los monjes benedictinos de Solesmes, destacando la figura de Dom Prosper Guéranger (1805-1875), quien había fundado la citada Abadía de Solesmes en 1833, donde creó un taller de paleografía musical con el fin de restaurar el canto llano según las antiguas fuentes, aplicando el método crítico-filológico al análisis de la música (Fernández de la Cuesta 1991; Combe 1969).

FIGURA 22

Dom Prosper Guéranger (1805-1875)

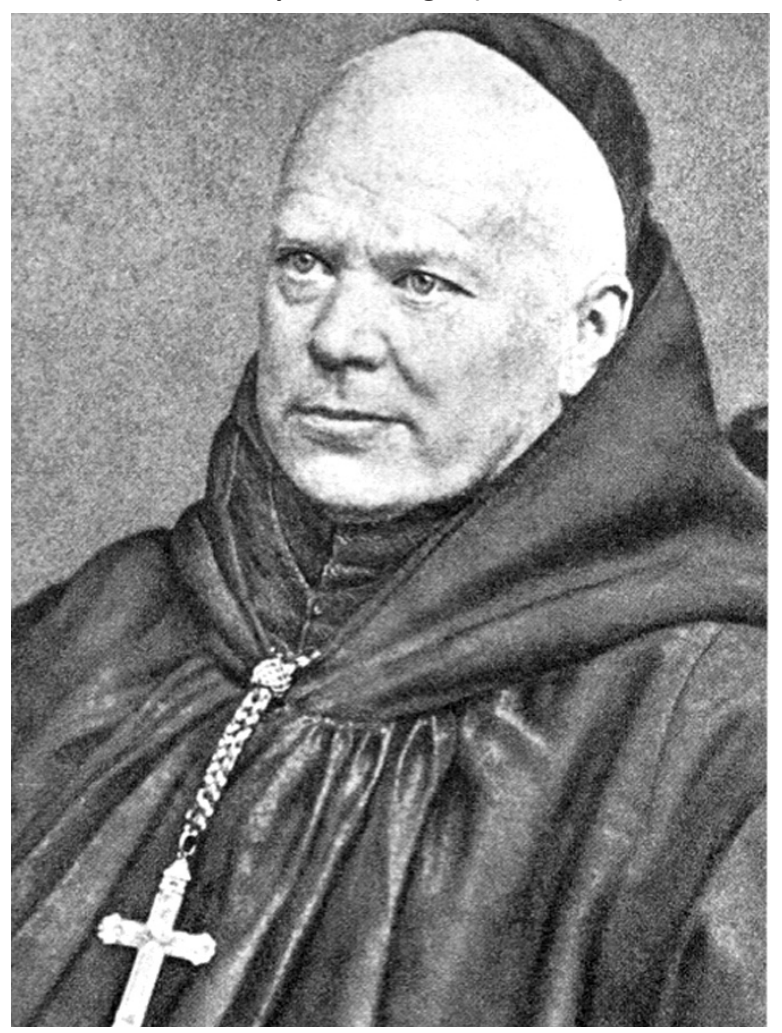

Fuente: Wikipedia. https://es.wikipedia.org/wiki/Prosper_Gu\%C3\%A9 ranger\#/media/Archivo:Prosper.jpg
Ya en una fecha tan temprana como 1860, el organista de la catedral de Burgos Agapito Sancho había publicado en Burgos dos volúmenes de canto llano: el primero contenía Misas de canto figurado, para todas las festividades del año y el segundo los Oficios de las festividades principales del Señor y de la Santísima Virgen, ambos formando parte de la colección Biblioteca de Música Sagrada (Virgili: 2004a). Sin embargo, la corriente restauradora cobró inusitado impulso al repoblar los benedictinos franceses el monasterio de Silos: tales monjes no solo traían consigo la práctica del canto litúrgico sino su estética basada en el valor primordial de la palabra, tal como señala Fernández de la Cuesta (2004). El ambiente restaurador propiciado en España por su presencia contribuyó a que se adoptaran una serie de conclusiones en el I Congreso Católico Nacional, celebrado en Madrid en 1889, que hacían referencia al canto gregoriano:

1. Debe sustituirse el canto llano que hoy está en uso por el canto gregoriano en relación con los adelantos modernos. 2 Como consecuencia de lo anterior, es necesario escribir un método que llene cumplidamente los deseos de todos. 3 El canto llano deberá acompañarse en su tonalidad propia y privativa, y conviene que el órgano no lleve la voz cantante sino que se limite a acordes tenidos, considerando el canto como verdadera melodía. 4 Una vez publicado el método, todas las oposiciones que se hagan a beneficios músicos serán en relación con dichos conocimientos. 5 Encarecer la necesidad, utilidad y conveniencia de que en la Escuela Nacional de Música se dé enseñanza de canto llano en conformidad con lo que ya tiene acordado el Consejo de Instrucción pública (Conclusiones recogidas en Uriarte 1890: $x-x i)$.

FIGURA 23

Tratado de Eustoquio Uriarte (1890)

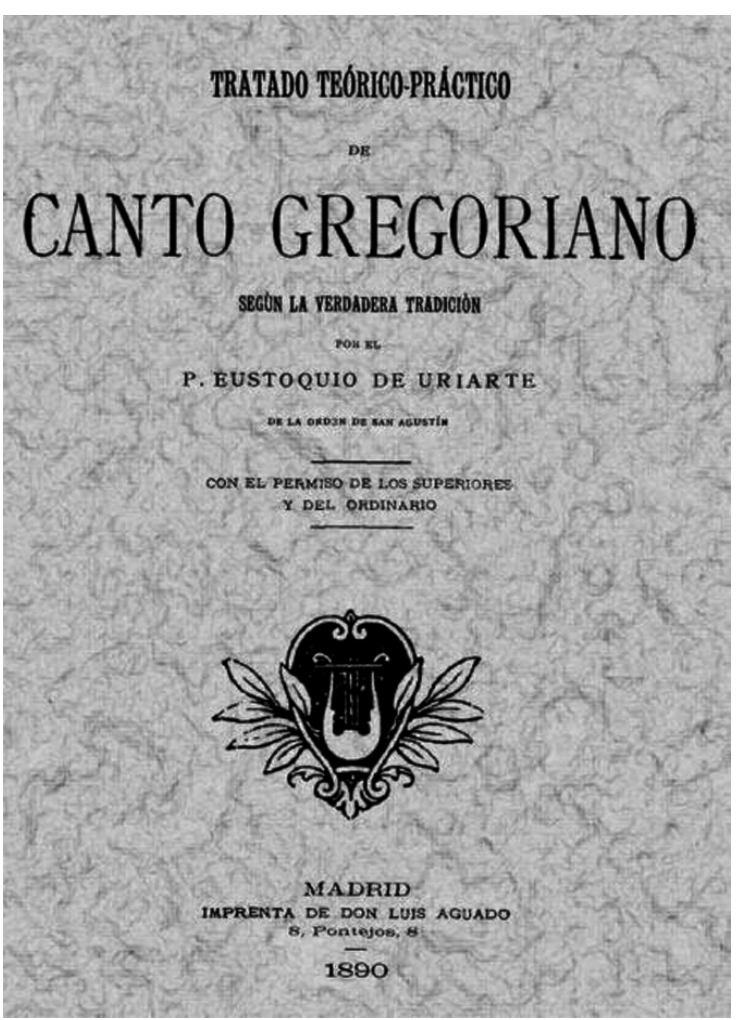

Fuente: Pasajeslibros.com. https://www.pasajeslibros.com/libros/ tratado-teorico-practico-de-canto-gregoriano-segun-la-verdaderatradicion/9788497613309/ 
A partir de entonces, la difusión del canto llano practicado en Solesmes y Silos fue obra del agustino del Escorial Eustoquio Uriarte, ${ }^{27}$ quien tras su estancia en Silos publicó su Tratado teórico-práctico de canto gregoriano en Madrid (1890), basado fundamentalmente en la obra de Dom Pothier Les mélodies grégoriennes de 1880 , por lo que se muestra fiel a los principios de la restauración solesmense, es decir, dar prioridad a la supeditación de la melodía al texto litúrgico y a la fidelidad a los testimonios antiguos, tanto los procedentes de fuentes teóricas como de los manuscritos con notación neumática.

Por otra parte, los intentos de reforma de la música sacra española no cesaron una vez entrado el siglo XX, como lo demuestra la celebración de diferentes congresos de música religiosa en las primeras décadas de ese siglo (López-Calo 1999c; Aviñoa 2004 y Capdepón 2014).

\section{CONCLUSIONES}

Si hasta el siglo XVIII puede afirmarse que el ámbito eclesiástico había constituido la principal fuente de trabajo para el músico español, a partir de comienzos del siglo XIX tal situación cambia radicalmente debido al empobrecimiento generalizado de las instituciones religiosas a causa del estallido de la Guerra de la Independencia y de las desamortizaciones que se sucedieron desde la instauración de los gobiernos liberales en nuestro país, si bien ya existieron medidas en este sentido desde la segunda mitad del siglo XVIII y a las que ya nos hemos referido en este artículo. La situación de decadencia generalizada que afectó a las capillas musicales de catedrales, colegiatas, monasterios o iglesias parroquiales se vio agravada por la firma del Concordato de 1851 entre el gobierno español y la Santa Sede, según el cual se reformó el mapa religioso español, suprimiéndose un buen número de capillas musicales, al reconvertirse por ejemplo algunas colegiatas en simples iglesias parroquiales.

Numerosas voces se alzaron en España frente al estado de deterioro de la música sacra, bien denunciado su situación, como es el caso del crítico José María Esperanza y Sola, bien proponiendo distintos proyectos de reforma desde mediados del siglo XIX, entre los cuales sobresalen los defendidos por compositores tan significados para nuestra historia musical como Hilarión Eslava, Francisco Asenjo Barbieri o Felipe Pedrell, preocupados por la progresiva desaparición de las capillas o por el estado de indigencia en el que se encontraban las capillas musicales catedralicias que habían logrado sobrevivir. Si bien dichos proyectos o iniciativas apenas hallaron eco, sin embargo sentaron las bases, en connivencia con el movimiento cecilianista europeo, para crear las circunstancias favorables que posibilitaran la creación de un nuevo canto religioso más sobrio, basado en modelos antiguos (fundamentalmente la polifonía palestriniana) así como la restauración del canto gregoriano, y por ello más acorde con las necesidades litúrgicas: tal concepción desembocaría en la promulgación del Motu Proprio por parte del Papa Pío X en 1903, que tuvo una gran impronta en nuestro país y en el desarrollo de la música eclesiástica española de la primera mitad del siglo XX.

27 Sobre la labor restauradora del canto gregoriano por parte del padre Eustoquio Uriarte, véase Asensio 1992.
Sin embargo, y a pesar de la adopción del citado nuevo estilo religioso en el canto litúrgico, tales intentos de reforma de la música eclesiástica española no alcanzaron sus principales objetivos en el sentido de recuperar el antiguo esplendor sonoro desplegado en las capillas musicales de nuestro país. Coincidiendo con la progresiva decadencia de las capillas musicales de nuestro país, en nuestra opinión las mencionadas capillas dejaron de desempeñar el papel educativo y artístico históricos que habían desempeñado en el pasado: por una parte, al desdeñarse por las autoridades educativas del país la novedosa e imaginativa propuesta de Hilarión Eslava de reconvertir las capillas musicales principales en sucursales del Conservatorio Nacional de Madrid, se perdió una ocasión única para extender la enseñanza musical en España, aprovechando la experiencia acumulada a lo largo de siglos de práctica musical por parte de los músicos eclesiásticos; por otra parte, el hecho significativo de que en 1869 estuvieran vacantes 23 magisterios de capilla, tal como denunciaba Francisco Asenjo Barbieri, indicaba que la medida emanada del Concordato de 1851 en el sentido de imponer la obligatoriedad del estado eclesiástico para los músicos que aspiraran a ejercer puestos musicales en las capilla musicales, significó un impedimento definitivo para consolidar y asegurar la continuidad gloriosa que en siglos pasados había experimentado la música sacra española.

\section{BIBLIOGRAFÍA}

Alonso, Celsa. 1998. La canción lírica española en el siglo XIX. Madrid: Instituto Complutense de Ciencias Musicales.

Ansorena, José Luis (ed.). 1978. Monografía de Hilarión Eslava. Pamplona: Diputación Foral de Navarra.

Ansorena, José Luis. 1999. «Eslava, Hilarión». En Diccionario de la Música Española e Hispanoamericana, dirigido por Emilio Casares, vol. 4, 748-759. Madrid: Sociedad General de Autores y Editores.

Antigüedad, María Dolores. 1987. José Bonaparte y el patrimonio artístico de los conventos madrileños. Tesis doctoral. Madrid: Universidad Complutense.

Arana Martija, José Antonio. 1976. Música Vasca. Bilbao: Caja de Ahorros Vizcaína.

Asensio, Juan Carlos. 1992. «El P. Eustoquio de Uriarte y la restauración del canto gregoriano en España». En La música en el Monasterio del Escorial, editado por Francisco Javier Campos y Fernández de Sevilla, 753-763. San Lorenzo del Escorial: Instituto Escurialense de Investigaciones Históricas y Artísticas.

Asensio, Juan Carlos. 2004. «La recepción del Motu Proprio en España: Federico Olmeda y su opúsculo Pío X y el Canto Romano». Revista de Musicología XXVII-1: 77-88.

AA. VV. Sin fecha. Apuntes biográficos del eminente maestro español D. Nicolás Ledesma, Maestro de Capilla de la Basílica de Santiago de Bilbao. Bilbao: Dotesio.

Aviñoa, Xosé. 2004. «Los congresos del Motu Proprio (1907-1928). Repercusión e influencias». Revista de musicología XXVII (1): 381400. https://doi.org/10.2307/20797857

Ayarra, José Enrique. 1979. Hilarión Eslava en Sevilla. Sevilla: Diputación Provincial.

Baldelló, Francesc. 1962. «La música en la basílica parroquial de Santa María del Mar de Barcelona». Anuario Musical XVII: 209-241.

Bonastre, Francesc. 1972. "Pedrell, precursor de la reforma musical litúrgica de 1903». Anuario Musical XXVII: 103-107.

Bonastre, Francesc. 1999. «Andreví Castellá, Francisco». En Diccionario de la Música Española e Hispanoamericana, dirigido por Emilio Casares Rodicio, vol. 1, 457-458. Madrid: Sociedad General de Autores y Editores. 
Bonastre, Francesc. 2001. «Pedrell, Felipe». En Diccionario de la Música Española e Hispanoamericana, dirigido por Emilio Casares Rodicio, vol. 8, 548-559. Madrid: Sociedad General de Autores y Editores.

Broto, Julio. 1986. Diccionario biográfico musical aragonés. Huesca: Artes Gráficas Alós.

Campos y Fernández de Sevilla, Francisco Javier. 2007. «Textos legales de las desamortizaciones eclesiásticas españolas y con ellas relacionados». En La desamortización: el expolio del patrimonio artístico y cultural de la Iglesia en España: actas del Simposium 6/9-IX-2007, 5-30. San Lorenzo del Escorial: Instituto Escurialense de Investigaciones Históricas y Artísticas.

Capdepón, Paulino. 2012a. La música en la Colegiata de Santa María la Mayor de Talavera de la Reina durante el siglo XVIII. Talavera de la Reina: Ayuntamiento.

Capdepón, Paulino. 2012b. «El editor Louis E. Dotésio y la publicación de las obras completas de Nicolás Ledesma (1791-1883)». En Imprenta y edición musical en España (ss. XVIII-XX), editado por Begoña Lolo y Carlos José Gosálvez, 325-342. Madrid: Universidad Autónoma de Madrid.

Capdepón, Paulino. 2013a. «La capilla de música de la Colegiata de Santa María la Mayor en Talavera de la Reina (Toledo)». Hispania Sacra 131: 181-237. https://doi.org/10.3989/hs.2013.007

Capdepón, Paulino. 2013b. «Decadencia y supresión de la capilla musical de la Colegiata de Talavera de la Reina en el siglo XIX: precedentes y causas». Cuadernos de Música Iberoamericana 25-26: 35-50.

Capdepón, Paulino. 2014. «La música religiosa española entre 1900 y 1936: la generación del Motu Proprio». En La Música acallada. Liber amicorum José María García Laborda, editado por Matilde Olarte y Paulino Capdepón, 67-82. Salamanca: Amaru.

Capdepón, Paulino. 2016a. «El Patrimonio musical de Talavera de la Reina». En El patrimonio musical de Castilla-La Mancha: nuevas perspectivas, editado por Paulino Capdepón y Juan José Pastor, 109-173. Madrid: Alpuerto.

Capdepón, Paulino. 2016b. «La recepción de la música de Mozart en España desde finales del siglo XVIII hasta 1832». En Mozart en España: estudios y recepción musical, editado por Paulino Capdepón y Juan José Pastor, 33-90. Vigo: Editorial Academia del Hispanismo.

Capdepón, Paulino. 2017. «La capilla musical de la Colegiata de Talavera de la Reina en la primera mitad el siglo XIX». Anuario Musical 72 165-184. https://doi.org/10.3989/anuariomusical.2017.72.07

Capdepón, Paulino. 2018a. «Andreví Castellá, Francisco». En Diccionario Biográfico Electrónico [En línea] http://dbe.rah.es/ biografias/19518/francisco-andrevi-castella

Capdepón, Paulino. 2018b. «Eslava Elizondo, Hilarión». En Diccionario Biográfico Electrónico [En línea] http://dbe.rah.es/ biografias/8913/hilarion-eslava-elizondo

Capdepón, Paulino. 2018c. «Rodríguez de Ledesma, Mariano Nicasio». En Diccionario Biográfico Electrónico [En línea] http://dbe.rah.es/ biografias/37205/mariano-nicasio-rodriguez-de-ledesma

Carreras, Juan José. 2018. Historia de la Música en España e Hispanoamérica. 5. La música en España en el siglo XIX. Madrid: Fondo de Cultura Económica.

Casares, Emilio. 1994. Francisco Asenjo Barbieri. Vol. 2 Escritos. Madrid: Instituto Complutense de Ciencias Musicales.

Casares, Emilio. 1995. "La música del siglo XIX español. Conceptos fundamentales». En La música española del siglo XIX, editado por Emilio Casares y Celsa Alonso, 13-122. Oviedo: Universidad de Oviedo.

Combe, Pierre. 1969. Histoire de la restauration du chant grégorien d'après des documents inédits. Solesmes: Abbaye Saint Pierre.

De Peque, Iñigo. 2012. "Nicolás Ledesma (1791-1883 y la producción organística del País Vasco en los siglos XVIII y XIX». Musiker 19: 311-359.

Elizondo, Esteban. 2002. La organería romántica en el País Vasco y Navarra. Bilbao: Servicio editorial de la Universidad del País Vasco.

Eslava, Hilarión. 1852-1860. Lira Sacro Hispana. Madrid: Mariano Martín Salazar.

Eslava, Hilarión. 1853. Museo Orgánico Español, vol. I. Madrid: José de la Peña impr.
Eslava, Hilarión. 1855. «Plan que se propone para las capillas y escuelas musicales». Gaceta musical de Madrid 3, 19 de febrero de 1855: 17-19.

Eslava, Hilarión. 1860. Breve memoria histórica de la música religiosa en España. Madrid: Imprenta de Luis Beltrán.

Esperanza y Sola, José María. 1906a. «Herejías musicales». En Treinta años de crítica musical, editado por José Ramón Mélida, vol. I, 75-86. Madrid: Est. tip. de la viuda e hijos de Tello.

Esperanza y Sola, José María. 1906b. «Necrología de Nicolás Ledesma». En Treinta años de crítica musical, editado por José Ramón Mélida, vol. 2: 41-58. Madrid: Est. tip. de la viuda e hijos de Tello.

Ezquerro, Antonio. 2012. Nicolás Ledesma (1791-1883). Obra completa para tecla. Zaragoza: Institución Fernando el Católico.

Ezquerro, Antonio. 2015. Música en imágenes. El maestro Nicolás Ledesma (Grisel, Zaragoza, 1791-Bilbao, 1883). Un músico en la España del siglo XIX. Madrid: Alpuerto.

Ezquerro, Antonio. 2016. Música en imágenes. Francisco Andreví (1768-1853). Músico de iglesia y compositor cosmopolita en un mundo cambiante. Madrid: Alpuerto.

Fernández de la Cuesta, Ismael. 1991. "La restauración del canto gregoriano en la España del siglo XIX». Revista de Musicología XIV-1 y 2: 481-488. https://doi.org/10.2307/20795472

Fernández de la Cuesta, Ismael. 2004. «La reforma del canto gregoriano en el entorno del Motu Proprio de Pío X». Revista de Musicología XXVII-1: 43-75. https://doi.org/10.2307/20797839

Flores Pena, Joaquín Julio. 2011. «Nicolás Ledesma García: un músico en la historia». laciesma.com [En línea] http://www.laciesma. com/ledesma.html

Gallego, Antonio. 1991. "Aspectos sociológicos de la música en la España del siglo XIX». Revista de Musicología XIV-1 y 2: 13-31. https://doi.org/10.2307/20795438

Garbini, Luigi. 2009. Breve Historia de la música sacra. Madrid: Alianza Música.

García Serrano, Federico. Sin fecha. «1808-1812: El expolio napoleónico». El Museo Imaginado [En línea] http://www.museoimaginado.com/2017/02/06/1808-1812-el-expolio-napoleonico/

Garrido, Tomás. 2002. «Rodríguez de Ledesma, Mariano». En Diccionario de la Música Española e Hispanoamericana, dirigido por Emilio Casares, vol. 9, 293-301. Madrid: Sociedad General de Autores y Editores.

Gevaert, F.-A. 1852. «Rapport à Mr. le Ministre de l'Intérieur sur l'état de la musique en Espagne». Bulletin de l'Académie Royale des Sciences, des Lettres et des Beaux-Arts de Belgique XIX, 1re. Partie, 184-205.

Gosálvez, Carlos José. 1995. La edición musical española hasta 1936. Madrid: Asociación Española de Documentación Musical.

Guaza, Carlos y Antonio Guerra. 1884a. «Don Hilarión Eslava». En Músicos, poetas y actores, 41-57. Madrid: Imprenta F. Maroto e hijos.

Guaza, Carlos y Antonio Guerra. 1884b. «Don Nicolás Ledesma». En Músicos, poetas y actores, 59-72. Madrid: Imprenta F. Maroto e hijos.

Heilbron, Mar (ed.). 2003. Mariano Rodríguez de Ledesma: Colección de cuarenta ejercicios o estudios progresivos de Vocalización (París, 1828c). Madrid: Consejo Superior de Investigaciones Científicas.

Heine, Christiane. 1997. «La idea de sonata en la música para piano de Nicolás Ledesma y Marcial del Adalid». Revista de Musicología XX-1: 535-551. https://doi.org/10.2307/20797437

Hernández Ascunce, Leocadio. 1978. Estudio bio-bibliográfico de don Hilarión Eslava. Pamplona: Diputación Foral de Navarra.

Llorens Castillo, Vicente. 1979. Liberales y románticos: una emigración española en Inglaterra, 1823-1834. Valencia: Castalia.

Lolo, Begoña. 1995. «La música en la Real Capilla después de la Guerra de la Independencia. Breve esbozo del reinado de Fernando VII». Cuadernos de Arte de la Universidad de Granada 26: 157-169.

Lolo, Begoña. 1996. «La Real Capilla de Madrid». Scherzo XI, no 103: 120-122.

López-Calo, José. 1991. «Felip Pedrell y la reforma de la música religiosa». Recerca musicològica 11-12: 157-209. 
López-Calo, José. 1999a. «Catedrales». En Diccionario de la Música Española e Hispanoamericana, dirigido por Emilio Casares, vol. 3, 434-447. Madrid: Sociedad General de Autores y Editores.

López-Calo, José. 1999b. "Cecilianismo». En Diccionario de la Música Española e Hispanoamericana, dirigido por Emilio Casares, vol. 3, 459-462. Madrid: Sociedad General de Autores y Editores.

López-Calo, José. 1999c. "Congresos de música religiosa». En Diccionario de la Música Española e Hispanoamericana, dirigido por Emilio Casares, vol. 3, 876-878. Madrid: Sociedad General de Autores y Editores.

López-Calo, José. 2006. «Hilarión Eslava (1807-1878), precursor del Cecilianismo en España». Príncipe de Viana 238: 577-608.

López-Calo, José. 2012. La música en las catedrales españolas. Madrid: Instituto Complutense de Ciencias Musicales.

Lozano, Antonio. 1895. La música popular, religiosa y dramática en Zaragoza desde el siglo XVI hasta nuestros días. Zaragoza: Tipografía de J. Sanz y Navarro.

Martín Martín, Teodoro. 2005. «Aproximación a los efectos de la desamortización sobre las capillas musicales». Letras de Deusto 35, no 109: 45-78.

Mercader Riba, Juan. 1972. «La desamortización en la España de José Bonaparte». Hispania 122: 587-616.

Miró Bachs, A. 1942. Cien músicos célebres españoles. Barcelona: Pentagrama.

Mitjana, Rafael. 1909. El maestro Rodríguez de Ledesma y sus Lamentaciones de Semana Santa. Málaga: Imprenta de El Cronista.

Mitjana, Rafael. 1993. Historia de la música en España. Madrid Ministerio de Cultura.

Morrison, Paul Edward. 1997. Caspar Ett at St Michael's in Munich. Evanston.

Myers Brown, Sandra. 2005. "Las desamortizaciones eclesiásticas del siglo XIX en España y sus consecuencias sobre la música (Madrid y Toledo)». Revista de Musicología XXVIII-1: 310-327. https://doi. org/10.2307/20798075

Myers Brown, Sandra. 2007. «La Música desamortizada. Consecuencias del proceso desamortizador en el patrimonio musical eclesiástico en el siglo XIX». En La desamortización: el expolio del patrimonio artístico y cultural de la Iglesia en España: actas del Simposium 6/9-IX-2007, editado por Francisco Javier Campos y Fernández de Sevilla, 77-100. San Lorenzo del Escorial: Instituto Escurialense de Investigaciones Históricas y Artísticas.

Nagore, María. 2000. «Ledesma García, Nicolás». En Diccionario de la Música Española e Hispanoamericana, dirigido por Emilio
Casares, vol. 6, 841-842. Madrid: Sociedad General de Autores y Editores.

Olmeda, Federico. 1903. Folk-lore de Castilla o Cancionero popular de Burgos. Sevilla: Librería de María Auxiliadora.

Palacios, Miguel Ángel. 2003. Federico Olmeda, un maestro de capilla atípico. Burgos: Ayuntamiento de Burgos.

Perpiñán, José. 1897. «Cronología de los maestros de capilla y organistas de la catedral de Segorbe». La música religiosa en España II, no 24: 380-383.

Rodríguez Suso, María del Carmen. 1999. «Bilbao». En Diccionario de la música española e hispanoamericana, vol. 2, 450-478. Madrid: Sociedad General de Autores y Editores.

Rubio, Samuel. 1978. "Eslava musicólogo. Lira sacro-Hispana». En Monografía de Hilarión Eslava. Primer centenario, 153-175. Pamplona: Diputación Foral de Navarra.

Rueda, Germán. 1996. Historia de España. 22. El reinado de Isabel II. La España liberal. Madrid: Historia 16 y Temas de Hoy.

Saint-Martin, Carmela. 1973. Don Hilarión Eslava. Pamplona: Diputación Foral de Navarra.

Subirá, José. 1959. "La música en la Real Capilla madrileña y en el colegio de niños cantorcicos». Anuario Musical XIV: 207-230.

Tortella, Gabriel. 1994. El desarrollo de la España contemporánea. Historia económica de los siglos XIX y XX. Madrid: Alianza Editorial.

Uriarte, Eustoquio de. 1890. Tratado teórico-práctico de Canto gregoriano según la verdadera tradición. Madrid: Imprenta de don Luis Aguado.

Ursprung, Otto. 1924. Restauration und Palestrina-Renaissance in der katholischen Kirchenmusik der letzten zwei Jahrhunderte. Augsburg: B. Filser.

Virgili, María Antonia. 1995. "La música religiosa en el siglo XIX español». En La música española del siglo XIX, editado por Emilio Casares y Celsa Alonso, 375-405. Oviedo: Universidad de Oviedo.

Virgili, María Antonia. 2004a. «Antecedentes y contexto ideológico de la recepción del 'Motu Proprio' en España». Revista de musicología XXVII-1: 23-42. https://doi.org/10.2307/20797838

Virgili, María Antonia. 2004b. "La música religiosa en el siglo XIX español». Revista Catalana de Musicologia II: 181-202.

Virgili, María Antonia. 2010. «El Canto Popular Religioso y la Reforma Litúrgica en España (1850-1915)». Aisthesis: Revista chilena de investigaciones estéticas 47: 175-186. https://doi.org/10.4067/ s0718-71812010000100012 